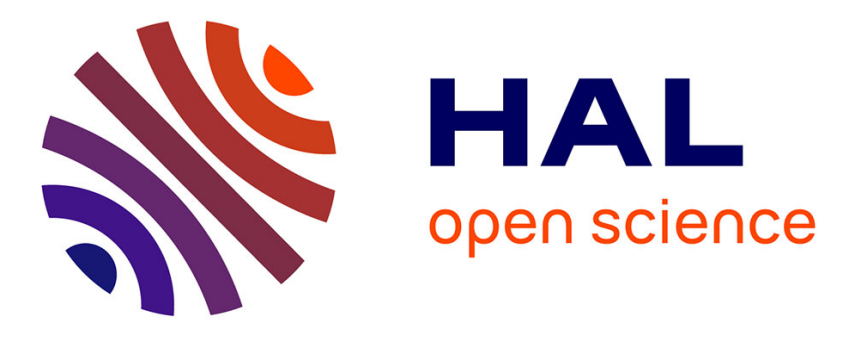

\title{
Pesticide transfer models in crop and watershed systems : a review
}

Charles Mottes, Magalie Lesueur-Jannoyer, Marianne Le Bail, Eric Maleziaux

\section{To cite this version:}

Charles Mottes, Magalie Lesueur-Jannoyer, Marianne Le Bail, Eric Maleziaux. Pesticide transfer models in crop and watershed systems: a review. Agronomy for Sustainable Development, 2014, 34 (1), pp.229-250. 10.1007/s13593-013-0176-3 . hal-01198184

\section{HAL Id: hal-01198184 https://hal.science/hal-01198184}

Submitted on 28 May 2020

HAL is a multi-disciplinary open access archive for the deposit and dissemination of scientific research documents, whether they are published or not. The documents may come from teaching and research institutions in France or abroad, or from public or private research centers.
L'archive ouverte pluridisciplinaire HAL, est destinée au dépôt et à la diffusion de documents scientifiques de niveau recherche, publiés ou non, émanant des établissements d'enseignement et de recherche français ou étrangers, des laboratoires publics ou privés. 


\title{
Pesticide transfer models in crop and watershed systems: a review
}

\author{
Charles Mottes • Magalie Lesueur-Jannoyer • \\ Marianne Le Bail • Eric Malézieux
}

Accepted: 9 August 2013

(C) INRA and Springer-Verlag France 2013

\begin{abstract}
Pesticides are now occurring worldwide in almost all water resources, thus threatening the health of humans and other life. As a consequence, there is a strong social demand for designing safe cropping systems with less or no hazardous pesticides. Safe cropping systems can be designed now using pesticide transfer models. These models are mathematical tools that allow to predict the flow and concentration of pesticides in a field or a watershed. Here, we review the effects of agricultural practices on runoff, leaching, erosion, and drift from eight watershed models and nine field models. Our main findings are the following: (1) though models claim they account for practices, their effects cannot be represented. We present a method and four practice levels to assess the effects of practices in models, using tillage as an example. (2) The conceptual structure of the model highly influences the predicted distribution and transfer of pesticides. For instance, the pesticide levels remaining on the soil surface after plowing ranges from $0 \%$ of the dose applied for the MIKE SHE-DAISY model to $100 \%$ for GLEAMS, annAGNPS, SoilFug, and PestLCI. Only the Root Zone Water Quality Model (RZWQM) simulates pesticide interception by mulch during pesticide application. (3) Models should better take into account mulching, e.g., plastic, crop residues and associated crops, and other innovative practices. (4) A change in scale is needed for drift in watershed models. Here, topological watershed representations are the most
\end{abstract}

\footnotetext{
C. Mottes $(\bowtie) \cdot$ M. Lesueur-Jannoyer

Cirad, UPR HortSys, Campus agro-environemental Caraïbe,

BP 214, 97285 Le Lamentin Cedex 2, Martinique, France

e-mail: charles.mottes@cirad.fr
}

\section{Le Bail}

AgroParisTech, UMR SADAPT, 16 Rue Claude Bernard,

75231 Paris Cedex 5, France

C. Mottes $\cdot$ M. Lesueur-Jannoyer $\cdot$ E. Malézieux

Cirad, UPR HortSys, 34398 Montpellier, France promising way for upscaling the effects of practices. (5) Nonconservative calculations of pesticide interception by watershed mitigation structures (SWAT) should be carefully checked because these calculations underestimate the risk of pollution at the outlet. How models simulate practices will no longer be a secret for model users who apply our methodology and recommendations when selecting a model. We provide recommendations for improving tools to assess practices.

Keywords Pesticides · Catchment - Watershed · Field . Agricultural practice $\cdot$ Best management practice $\cdot$ Mitigation practice $\cdot$ Model $\cdot$ Water pollution

Contents

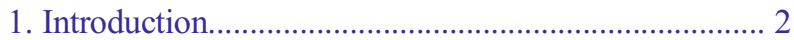

2. Methodology.................................................................. 3

2.1. Model selection..................................................... 3

2.2. Conceptual framework............................................ 4

2.3. Selection of practices and processes.........................5

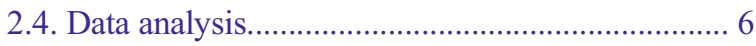

3. Levels of integration of practices......................................

3.1. Continuous and event models................................. 8

3.2. Tillage and runoff................................................... 9

3.3. Tillage and erosion................................................ 10

3.4. Data requirements................................................ 10

4. Pesticide distribution.......................................................10

4.1. Tillage effects................................................................. 11

4.2. Pesticide application practices............................... 11

5. Innovative practices: ground cover management........12

5.1. Tillage and ground cover........................................ 13

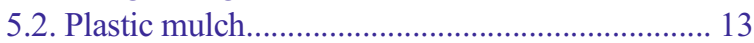

5.3. Dead mulch............................................................... 13

5.4. Crops, weeds, and cover crops.............................. 13

6. Upscaling practices....................................................... 14

6.1. Space representation............................................. 14 
6.2. Drift modeling. 14

7. Practices at the catchment scale. .15

7.1. Ditches and waterways. .. 15

7.2. Buffer zones. 16

8. Conclusions.. 16

\section{Introduction}

In agriculture, the control of pests and weeds has always been a major problem worldwide. Since the 1930s-1940s, several families of chemical compounds have been synthesized to protect crops against pests and weeds while increasing yield and commercial quality (Fournier 2006; van der Werf 1996). This contributed to an unsustainable increase in yield, while pesticides and metabolites were spread throughout the environment with potentially negative impacts on ecosystems (Tilman et al. 2002) and on human health. Nowadays, despite progress in using ecological processes to manage agro-systems with less chemicals (Altieri 1995; Altieri and Nicholls 2000; Kogan 1998; Malézieux 2012; Rosset and Altieri 1997), in practice, the use of pesticides is still widespread and even in innovative practices such as no-till systems coupled with the use of herbicides (Alletto et al. 2010; Carof et al. 2007; Roger-Estrade et al. 2009).

Capel et al. (2001) analyzed the behavior of 39 pesticides at different scales in the USA and showed that the annual load of pesticides in streams as a percentage of use is usually less than $2 \%$ in large catchments ( $>100,000$ ha). However, even if the rates of pesticides reaching rivers are usually low in catchments, pesticides pollute environmental compartments and food, leading to sanitary (Hjorth et al. 2011) and eco-toxicological issues (Chapman and Stranger 1992; Desneux et al. 2007; Tanji 1993; Warren et al. 2003). The impact of pesticides on the environment ranges from ecosystem disruption to human health risks related to the contamination of drinking water and food (Cabidoche and Lesueur-Jannoyer 2012; Daam and den Brink 2009; Finizio et al. 2001; Kruhm-Pimpl 1993).

The main processes involved in the fate of pesticides are degradation, retention, volatilization, drift, atmospheric dispersion, runoff, and leaching (Calvet et al. 2005; van Dijk and Guicherit 1999; Holvoet et al. 2007; Schiavon et al. 1995; van der Werf 1996). Once applied, the transfer of pesticides in the catchment depends on catchment hydrologic characteristics (Abbott et al. 1986a; Blanchard and Lerch 2000). Modeling these processes is one way to account for the response of a catchment to the combination of agricultural practices, the effects of which are difficult to test experimentally at such a scale (Arnold et al. 1998).

A catchment outlet combines the effects of agricultural practices and natural processes occurring at the catchment scale, including the type, timing, and spatial position of the processes and practices (Fig. 1). Many field-scale models have been developed to simulate pesticide transfer at field borders (Dubus and Surdyk 2006; Siimes and Kämäri 2003). In parallel, catchment scale models such as European Hydrological System (SHE) (Abbott et al. 1986b) or TOPMODEL (Beven and Kirkby 1979) have been developed. Catchment models provide a simplified virtual representation of catchment functioning. Most catchment models simulate water and pollutant transfers. With increasing concern about water pollution by agricultural pesticides, there is the crucial need for models that deal with both scales. It is a known fact that, due to emergent processes at the catchment scale, the functioning of a catchment is more complex than a simple linear combination of emissions at the field scale (Cerdan et al. 2004; Shaman et al. 2004; Sivapalan 2006). However, catchment scale models were not designed to take the effects of agricultural practices on catchment response into account. Hence, the issue of including the effects of field-scale agricultural practices in catchment scale models has led to the development of new models that can account for agricultural practices when estimating the contamination of streams by pesticides (Arnold et al. 1998).

As summarized by Kauark Leite (1990), pesticide transfer models at the catchment scale can serve several purposes: (a) estimating pollutant fluxes, (b) estimating the risk of exceeding a particular concentration, (c) describing and identifying transport mechanisms, (d) locating and quantifying the importance of pollution sources, and (e) evaluating the effects of agricultural practices on water quality. Assessing cropping system scenarios at the landscape scale is a major objective for agronomists (Martin et al. 2006; Meynard et al. 2001). Catchment scale models can help diagnose and identify combinations of practices and other environmental factors that contribute to water contamination by pesticides at the watershed outlet (Biarnes and Colin 2006; Luo and Zhang 2009). Catchment scale models may also be able to determine whether changes in practices will have a beneficial effect on water quality (Arabi et al. 2007). The results of the simulations can be used to categorize scenarios based on their potential effect on water quality (Tixier 2004; Tixier et al. 2007; Zhang and Zhang 2011). A major challenge today is designing management-oriented assessment tools that can be more easily used by catchment managers (Quilbé and Rousseau 2007), agricultural advisors (Bockstaller et al. 2008), or farmers themselves (Barreteau et al. 2008).

Although catchment scale models have been reviewed several times (Beckers and Degré 2011; Borah and Bera 2003; Holvoet et al. 2007; Payraudeau and Gregoire 2012; Quilbé et al. 2006), these reviews focused on processes rather than on agricultural practices. Knowledge about practices is needed in models so that agronomists, managers, and developers can simulate existing and innovative practices. Modeling knowledge about farming practices will also help identify further research needs to enable the representation of agricultural 

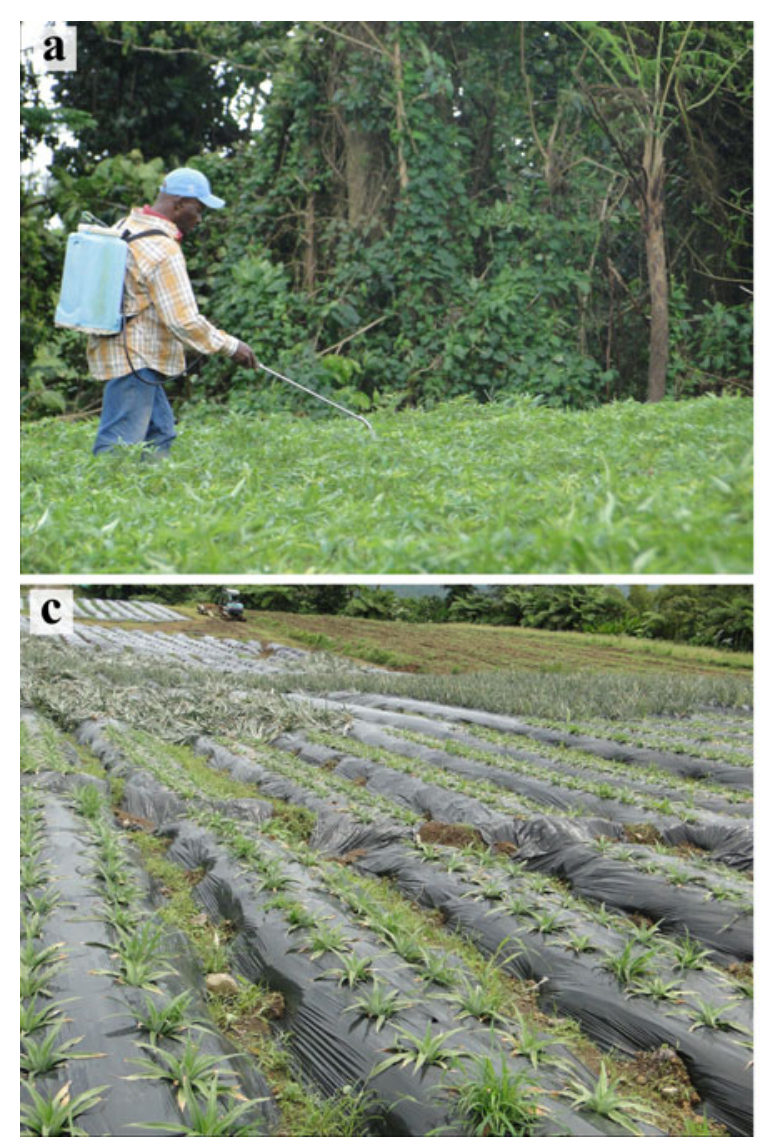

Fig. 1 Examples of agricultural practices which affect pesticide transfers in catchments: pesticide application (a), dead mulch ground cover (b), plastic mulch ground cover (c). Catchments are combinations of spatial

practices in catchment scale models. Here, we propose a conceptual framework to determine if and how pesticide transfer models represent the effects of agricultural practices on the contamination of water by pesticides.

\section{Methodology}

\subsection{Model selection}

The models we identified for review and associated references are summarized in Table 1. In the first step, we selected models representing whole catchments, not only specific catchment structures. Models were selected to represent the different types of catchment models identified in previous reviews: Following Quilbé et al. (2006), we selected management models (Soil and Water Assessment Tool (SWAT), annualized-Agricultural NonPoint Source (annAGNPS), Hydrological Simulation Program-Fortran (HSPF)), research models (MIKE SHE, Distributed Hydrological Modeling of Agrosystems (MHYDAS)), and multimedia models (SoilFug). Following Payraudeau and Gregoire (2012), MIKE SHE and MHYDAS represent physically based models; SWAT, annAGNPS, and
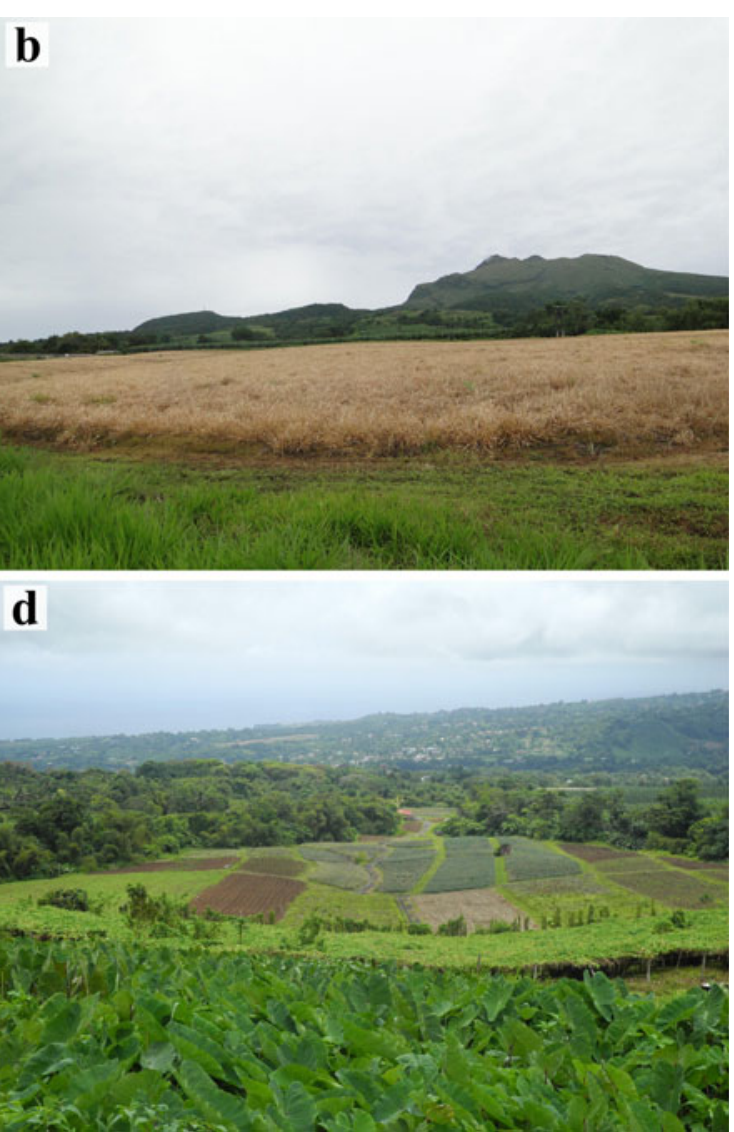

units with different environmental characteristics resulting from practices (d) (photos from Lesueur-Jannoyer)

HSPF represent conceptual models; and an environmental indicator (I-phyBV) was added to our selection set. Because of the huge amount of data needed to run simulation models, researchers are particularly interested in developing methods that require fewer input data such as multimedia models (Mackay 2001) or environmental indicators. Environmental indicators have been optimized for management purposes which makes them good candidates for the assessment of practices by agronomists (Devillers et al. 2005; Maraite et al. 2004; Wohlfahrt et al. 2010). To ensure that the selected assessment tools were representative of their diversity, we searched the Web of Knowledge up to May 2012 using the following keywords: " $[$ Topic $=($ model $*)$ AND Topic $=($ pesticide* $)$ AND Topic $=($ practice $*)$ AND $($ Topic $=($ catchment* $)$ OR

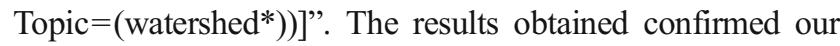
preselected list of assessment tools. For purposes of comparison, we completed the set of models with the geo-Pesticide Emission Assessment at Regional and Local scales (geoPEARL) model (a physically based research model) that assesses the contribution of practices to groundwater loading by pesticides at a regional scale. Finally, we searched for available documentation to validate the height assessment tools at the catchment scale: annAGNPS, geoPEARL, HSPF, I-phyBV, MHYDAS, MIKE 
Table 1 Models and associated references

\begin{tabular}{|c|c|}
\hline Models & References \\
\hline annAGNPS & $\begin{array}{l}\text { Young et al. } 1994^{\mathbf{a}} ; \text { Bingner et al. } 2011^{\mathbf{b}} \text {; } \\
\quad \text { Young et al. } 1989^{\mathbf{c}} ; \text { Yuan et al. } 2008^{\mathbf{e}}\end{array}$ \\
\hline geoPEARL & $\begin{array}{l}\text { Tiktak et al. } 2003^{\mathbf{a}, \mathbf{b}} ; \text { Tiktak et al. } 2004^{\mathbf{a}} \text {; } \\
\text { Tiktak et al. } 2002^{\mathbf{c}, \mathbf{e}}\end{array}$ \\
\hline GLEAMS & $\begin{array}{l}\text { Knisel and Walter } 1993^{a, b} ; \text { Leonard et al. } 1987^{c} ; \\
\text { Knisel et al. } 1995^{d} ; \text { Knisel et al. } 1989^{e} ; \\
\text { Magliola and Knisel } 1992^{e}\end{array}$ \\
\hline HSPF & $\begin{array}{l}\text { Bicknell et al. } 1996^{\mathbf{a}, \mathbf{b}} \text {; Donigian et al. } 1995^{\mathbf{c}} \text {; } \\
\text { Mohamoud et al. } 2010^{\mathbf{d}}\end{array}$ \\
\hline I-pest & van der Werf and Zimmer $1998^{c}$; Roussel et al. $2000^{e}$ \\
\hline I-phyBV & Thiollet-Scholtus $2004^{\mathbf{c}}$; Wohlfahrt $2008^{\mathbf{c}}$ \\
\hline$M A C R O$ & $\begin{array}{l}\text { Stenemo and Jarvis } 2010^{a} \text {; Larsbo and Jarvis } 2003^{b} \text {; } \\
\quad \text { Jarvis et al. } 1997^{c}\end{array}$ \\
\hline MHYDAS & $\begin{array}{l}\text { Charlier } 2007^{\mathbf{b}} \text {; Moussa et al. } 2002^{\mathbf{c}} ; \\
\quad \text { Moussa et al. } 2010^{\mathbf{c}} \text {; Moussa et al. } 2003^{\mathrm{e}}\end{array}$ \\
\hline MIKE SHE & $\begin{array}{l}\text { DHI } 2007 \mathrm{a}^{\mathbf{a}} \text {; DHI } 2007 \mathrm{~b}^{\mathbf{b}} \text {; Styczen et al. } 2004^{\mathbf{b}} \text {; } \\
\text { Abbott et al. } 1986 \mathrm{a}, \mathrm{b}^{\mathbf{c}} \text {; Refsgaard and } \\
\text { Storm } 1995^{\mathbf{c}} ; \text { Styczen et al. } 1999^{\mathbf{e}} \text {; } \\
{\text { de Bruyn et al. } 2006^{\mathrm{e}}}\end{array}$ \\
\hline PEARL & Tiktak et al. $2000^{a} ;$ Leistra et al. $2001^{b}$ \\
\hline PestLCI & Birkved and Hauschild $2006^{c}$ \\
\hline$P R Z M$ & Suarez $2005^{a, b}$; Carsel et al. $1985^{c}$ \\
\hline$R$-pest & Tixier $2004^{b, e}$; Tixier et al. $2007^{c, e}$ \\
\hline$R Z W Q M$ & $\begin{array}{l}\text { Ahuja et al. } 2000^{b} ; \text { Wauchope et al. } 2004^{b} \text {; } \\
\text { Ma et al. } 2001^{c, d} ; \text { Malone et al. } 2004^{e}\end{array}$ \\
\hline SoilFug & $\begin{array}{l}\text { Barra et al. } 1995^{\mathbf{c}} \text {; Barra et al. } 2000^{\mathbf{c}} \text {; } \\
\text { di Guardo et al. } 1994^{\mathbf{c}}\end{array}$ \\
\hline SWAT & $\begin{array}{l}\text { Arnold et al. } 2011^{\mathbf{a}} \text {; Neitsch et al. } 2011^{\mathbf{b}} \text {; } \\
\text { Arnold et al. } 1998^{\mathbf{c}} \text {; Srinivasan et al. } 1998^{\mathbf{c}} \text {; } \\
\text { Arabi et al. } 2008^{\mathbf{d}} \text {; Zhang and Zhang } 2011^{\mathbf{e}}\end{array}$ \\
\hline
\end{tabular}

Catchment scale models are in bold; field-scale models are in italics

${ }^{\mathrm{a}}$ User manuals

${ }^{\mathrm{b}}$ Technical or theoretical guides

${ }^{\mathrm{c}}$ General or initial publications

${ }^{\mathrm{d}}$ Publication on practices

${ }^{\mathrm{e}}$ Model uses

SHE, SoilFug, and SWAT. To avoid unnecessary repetition, the term "model" is used hereafter to qualify all selected assessment tools including simulation models and indicators.

Analysis of the structure of the MIKE SHE, MHYDAS, and HSPF models showed that they were developed primarily at the catchment scale. The other models were based on previously developed pesticide transfer models at the field scale (Chemicals, Runoff, and Erosion from Agricultural Management Systems (CREAMS), Groundwater Loading Effects of Agricultural Management Systems (GLEAMS), PEARL, and I-pest). The field-scale models have been adapted so they can be incorporated in catchment scale models, and as a result, they do not exactly match the standalone field-scale versions. Two catchment scale models (HPSF and MIKE SHE) have been bridged to field-scale models to improve their representation of field-scale practices and processes. Pesticide Root Zone Model (PRZM) was bridged to HSPF by the PZ2HSPF Bridge Program (Suarez 2005), and DAISY (Abrahamsen and Hansen 2000) and MACRO were bridged to MIKE SHE (van der Keur et al. 2011; Styczen et al. 1999). Pesticide transfer models at the field-scale and crop models coupled with pesticide transfer models at the catchment scale are summarized in Table 2.

In the second step, we selected field-scale models for review because they were developed specifically to assess the effects of agricultural practices on pesticides transfers at the field border and are used to generate inputs for catchment models. We found three field-scale models (Root Zone Water Quality Model (RZWQM), R-pest, and PestLCI) with documented descriptions of practice. As to our knowledge, they had not been associated with pesticide transfer models at the catchment scale; we also reviewed them for the purpose of comparison. GLEAMS is an update of CREAMS with improved groundwater capacities (Knisel and Walter 1980; Leonard et al. 1987), so we only reviewed GLEAMS.

For each model, we selected a set of documents including the manual, the technical guide, publications associated with the development of the model, and publications related to its use for diagnosis or simulation studies (Table 1). When the authors published a special paper to explain how to represent agricultural practices in the model, the paper was included in the set. Unfortunately, not all documents were available for the models we selected (Table 1). This finding revealed a lack of homogeneity in the framework associated with model development and documentation, especially for user manuals, and the focus of this review: publications on practices.

\subsection{Conceptual framework}

In agricultural catchments, pesticides may be applied on fields (Real 2004), on field borders such as hedges (Moonen and Marshall 2001), and on tracks and roads (Huang et al. 2004).

Table 2 Catchment scale models and associated field-scale models

\begin{tabular}{lll}
\hline Catchment models & $\begin{array}{l}\text { Field-scale } \\
\text { pesticide models }\end{array}$ & $\begin{array}{l}\text { Field-scale } \\
\text { crop models }\end{array}$ \\
\hline annAGNPS & CREAMS & EPIC \\
geoPEARL & PEARL & WOFOST \\
HSPF & Included/PRZM & Generic \\
I-phyBV & I-pest & None \\
MHYDAS & Included & None \\
MIKE SHE & MIKE SHE AD/ & Included/MACRO/ \\
& MACRO/DAISY & DAISY \\
SoilFug & Included & Simple \\
SWAT & GLEAMS & EPIC
\end{tabular}

Each line of the table shows the field-scale pesticide and crop models that have been integrated or bridged to each catchment model 
As diffuse pollution results from pesticides applied on fields (Levillain et al. 2012), we focused on the effects of agricultural practices on the fate of pesticides applied on fields.

At field and catchment scales, the general mechanisms that influence pesticide transfers can be represented as shown in Fig. 2: (i) Agricultural practices modify variables describing environmental characteristics (such as soil hydraulic properties or ground cover) of one or more environmental compartments (such as soil or plants). (ii) Variables describing environmental characteristics modify the response of the simulated processes according to the variables defining the climate. (iii) The resulting hydrologic and biophysical processes modify environmental characteristics. For instance, tillage affects (i) soil hydraulic properties which, in turn, modify (ii) different hydrologic processes (leaching, runoff) that occur in soil after a rainfall event (Alletto et al. 2010). The resulting water fluxes modify (iii) the pesticide content and distribution in the soil due to leaching or runoff. In Fig. 2, decisional relationship arrows represent the farmer's decisions concerning which practices to use in a given field depending on its climatic and environmental characteristics. For instance, herbicide applications can use a threshold based on weed height, but no herbicide applications are performed on rainy days. In this review, we focused on the simulation of the effects of practices on points (i) and (ii) only. The effects of processes on environmental characteristics as well as decision models for applications of practices are not discussed in this article.

\subsection{Selection of practices and processes}

We review models at both the field and the catchment scales. The models have different objectives and thus do not simulate exactly the same categories of processes. Field models simulate production of flows but do not simulate flow transfers, whereas catchment models simulate both the production and transfer of flows. We took this difference into account in the selection of the practices and processes analyzed in our review. The relations between practices and processes analyzed in this review are not exhaustive but suffice to discuss the conclusions which can be drawn by using our conceptual analysis framework. Holvoet et al. (2007) report that contamination of rivers can be significantly reduced by reducing pesticide use and by applying practices to control runoff and erosion, along with drift reducing measures. We thus chose to analyze the effects of practices on runoff/infiltration, erosion, and drift. These processes are produced at field scale and transferred at catchment scale making it possible to discuss the change in scale. The main environmental characteristics found to affect pesticide transfers toward the identified processes were ground cover, soil water content, the distribution of pesticides in the different environmental compartments, soil hydraulic properties, soil erodibility, and soil organic matter content (Alletto et al. 2010; Leonard 1990). The main fieldscale practices found to affect the above-mentioned environmental characteristics were pesticide application, tillage, manure application, mulching, cover cropping, crop plantation, crop harvest, mowing, clearing, pruning, and irrigation (Alletto et al. 2010; Hartwig and Ammon 2002; Walter et al. 1979). We selected four types of practices based on their effects: (1) pesticide applications make pesticides available in the different environmental compartments; (2) tillage, which has drastic effects on most of the environmental characteristics that affect pesticide transfer (soil hydraulic properties, soil erodibility, soil ground cover, soil organic matter, and pesticide distribution in soil); (3) practices associated with the management of ground cover (tillage, impervious mulching, mulching using plant residues, cover cropping, crop plantation, crop harvest, mowing, clearing, and pruning), which make it possible to compare the models' representation of innovative practices (impervious mulching, plant residue mulching, cover cropping) with their representation of conventional practices (tillage); and (4) catchment practices that interact with pesticide flows. The catchment practices identified as affecting pesticide flow in catchments were buffer zones, waterways, ditches, tile drainage, and ponds (Reichenberger et al. 2007; Rice et al. 2007).

To conduct a broad yet in-depth analysis of the modeled agricultural practices, we selected specific relationships

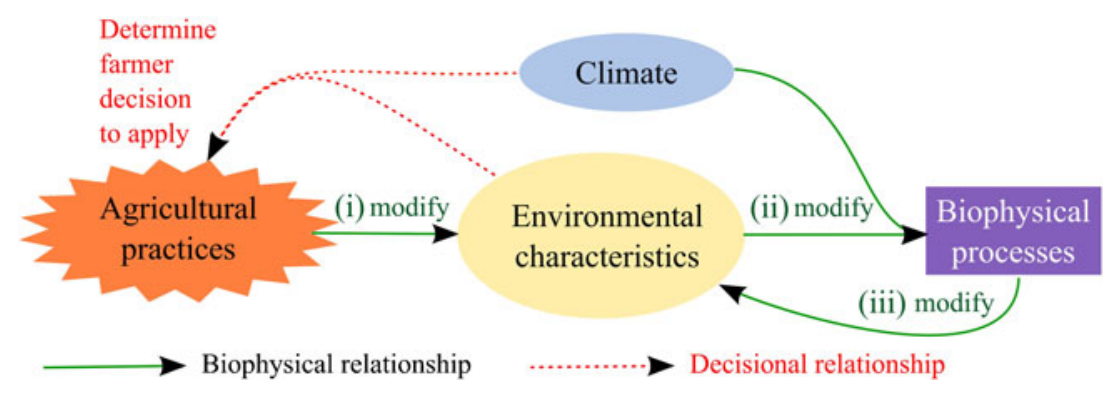

Fig. 2 Relationships between agricultural practices and pesticide transfer related processes: $(i)$ Agricultural practices modify variables describing environmental characteristics (such as hydraulic properties or ground cover). (ii) Variables describing environmental characteristics modify

the response of the simulated processes according to the variables defining climate. (iii) The resulting processes modify the environmental characteristics 
between practices and processes (Table 3 ). Other processes or practices were not included in our in-depth analysis either because the lack of information on the effect of certain practices (retention, degradation) would spoil the comparison or because their representation was not a priority for catchment modelers (volatilization).

\subsection{Data analysis}

First, we compared models on the basis of whether they accounted for our subset of selected practices (pesticide application, tillage, and mulching) (Table 4). It is important to note that this study relies on a literature analysis only. None of the models we reviewed were tested. We analyzed the methods and scientific knowledge used to represent the effect of identified practices on runoff, infiltration, erosion, and drift according to our conceptual framework. Then, we classified our results under five points with illustrations of specific practices:

We found different levels of integration of practices in models. We discuss the levels of integration based on the effects of tillage on runoff through soil hydraulic properties and soil cover and the effects of tillage on erosion through erodibility (Section 3). We found different pesticide application practices represented in models as well as various tillage mixing algorithms and wondered about their effects on pesticide transfers (Section 4). We discuss whether models simulate innovative agricultural practices by analyzing practices related to ground cover management (impervious plastic mulching, mulching using plant residues, and associated cover cropping) (Section 5). We discuss problems of changes in scale by analyzing how space is represented in catchment models and how drift and drift redeposition are modeled (Section 6). We also checked whether and how catchment practices (buffer zones and ditches) had been integrated in the models (Section 7).

In Section 4, we compare the algorithms used to represent the effects of tillage on pesticide distribution in the soil profile by simulating pesticide distribution in soil layers using the tillage algorithms found in the models. To this end, we simulated a moldboard plow tillage operation at $30 \mathrm{~cm}$ depth from an initial situation of $10 \mathrm{~kg} \mathrm{ha}^{-1}$ of pesticides applied to the first $1 \mathrm{~cm}$ of the soil. For the simulation, the soil was represented as having 11 layers and a depth of $50 \mathrm{~cm}$. The first layer was $10 \mathrm{~mm}$ deep, the second $40 \mathrm{~mm}$, and the other eight were each $50 \mathrm{~mm}$ deep. Figure 4 presents the simulation results.

\section{Levels of integration of practices}

Table 4 summarizes the reviewed cropping system practices implemented in pesticide transfer models at both catchment and field scales. To illustrate the levels of integration of practices in the models, we focused on the effect of tillage on runoff and erosion through soil hydraulic properties, soil cover, and soil erodibility. Using the analytical framework depicted in Fig. 2, we found four levels of integration of the effect of a practice on processes related to pesticide transfers (Fig. 3):

Level 1: The process is not represented by the model. As a result, the effects of practices on the process cannot be represented. For instance, MACRO, PEARL, geoPEARL, I-pest, I-phyBV, PestLCI, RZWQM, and SoilFug models do not have an erosion module, which implies that tillage

Table 3 Relationships between practices, environmental characteristics, and processes analyzed in the review

\begin{tabular}{|c|c|c|c|}
\hline Practices & Environmental characteristics & Processes & Sections \\
\hline Tillage & Soil hydraulic properties & Runoff/infiltration & 3.2 \\
\hline Tillage & Erodibility & Erosion & 3.3 \\
\hline Tillage & Ground cover & Runoff/infiltration & $3.2-5.1$ \\
\hline Tillage & Ground cover & Erosion & $3.3-5.1$ \\
\hline Tillage & Pesticide vertical distribution in soil & Runoff/infiltration & 4.1 \\
\hline Pesticide application & $\begin{array}{l}\text { Amount of pesticides in environmental } \\
\text { compartments }\end{array}$ & $\begin{array}{l}\text { Various depending on models and } \\
\text { compartments }\end{array}$ & 4.2 \\
\hline Pesticide application & Amount of pesticide in air & Drift redeposition & 6.2 \\
\hline Plastic mulching & Impervious ground cover & Multiple, no specific example & 5.2 \\
\hline Crop residues mulching & Pervious ground cover & Multiple, no specific example & 5.3 \\
\hline Cover crop mulching & Pervious ground cover & Multiple, no specific example & 5.4 \\
\hline Ditch and waterway & Vegetative cover and size & Runoff and erosion interception & 7.1 \\
\hline Buffer zone & Vegetative cover and size & Runoff and erosion interception & 7.2 \\
\hline
\end{tabular}

Each line corresponds to a relationship. The first column gives the practice, the second column gives the environmental characteristic affected by the practice, and the third column gives the process affected by the modification of the environmental characteristic. The last column indicates the sections of the article discussing each relationship 


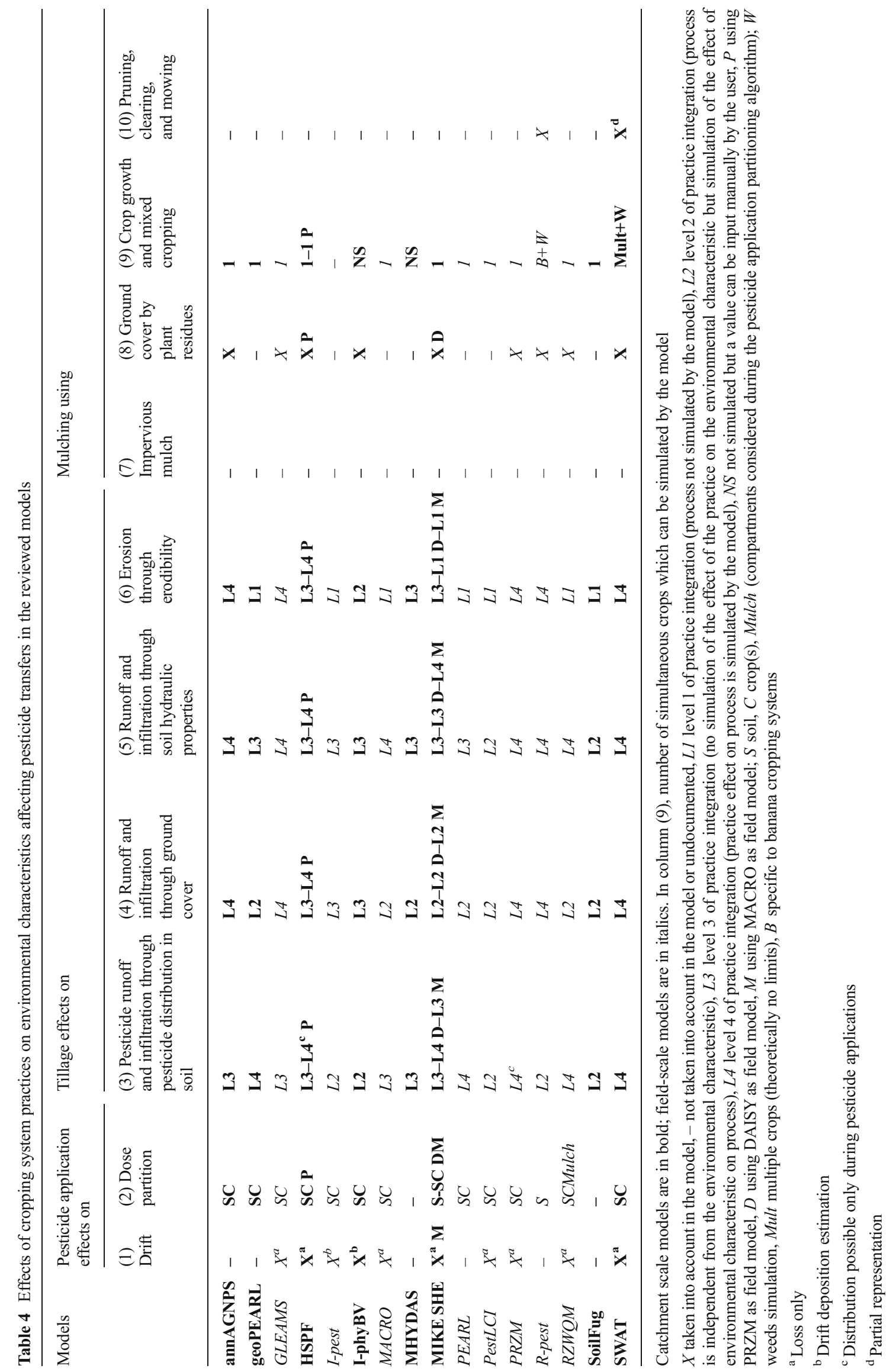




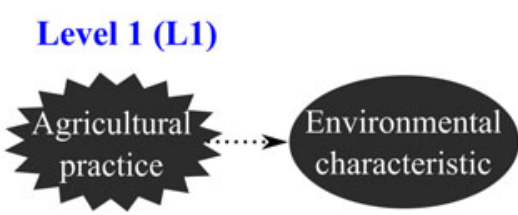

The process is not represented by the model. The effect of a practice on the process cannot be simulated.

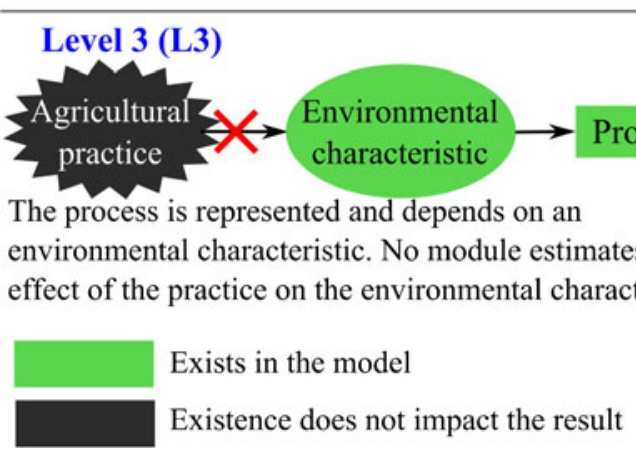

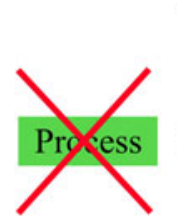

In (1)

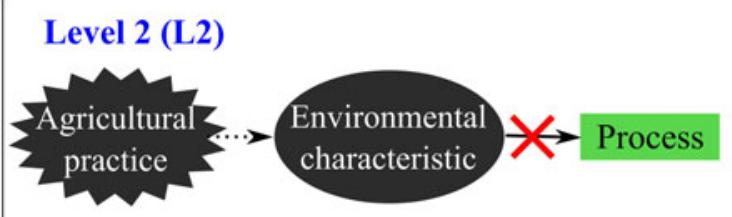

In the model, the process exists but the environmental characteristic has no effect on the process.

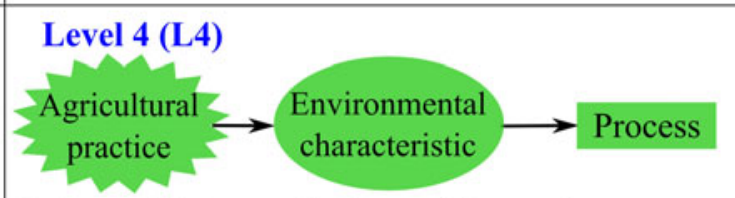

In the model, the practice has an effect on the process by modifying an environmental characteristic.

Does not exist in the model

Relationship simulated by the model

Simulation of the relationship does not impact the result

Fig. 3 The four levels of integration of the effect of agricultural practices on processes in models

operations do not affect pesticide transfers through erosion even though it is known that tillage affects soil structure hence favoring soil and soil-bound pesticide transfers (Alletto et al. 2010; Takken et al. 2001)

Level 2: The process is represented by the model, but the environmental characteristic has no effect on the process or, in continuous models, the environmental characteristic cannot be modified during the course of the simulation. For instance, SoilFug simulates the runoff process, but the process does not depend on soil hydraulic properties. PestLCI has a parameter that partially represents soil hydraulic properties, but it depends only on sand content of the soil and cannot be modified even though it is known that tillage affects soil hydraulic properties leading to modifications in runoff and infiltration processes (Cresswell et al. 1993; Wu et al. 1992).

Level 3: The process is represented and depends on an environmental characteristic. However, there is no module in the model to estimate the effect of the practice on the environmental characteristic concerned. For instance, HSPF, MHYDAS, MIKE SHE, and I-phyBV simulate runoff and infiltration. They have parameters that are presented as being modified by tillage practices. However, the value of the parameters has to be supplied by the user and is not simulated by a module in the model. Level 4: Environmental characteristics and the process are fully integrated in the model. Environmental characteristic values are calculated from the application of practices and have direct or indirect effects on pesticide transfer processes. For instance, GLEAMS, MACRO, RZWQM, R-pest, PRZM, SWAT, and annAGNPS simulate the effect of tillage on soil hydraulic properties which in turn affects the runoff and infiltration processes and the resulting pesticide transfers.

Table 4 shows that most models do not simulate erosion and are thus unable to assess the effects of any practice on pesticide transfers caused by erosion. Most field-scale models integrate the effects of tillage on runoff and infiltration at level 4. In catchment scale models, except for annAGNPS and SWAT, the integration of the effects of tillage is below level 4. Nevertheless, the levels of integration are improved by bridging catchment scale models to field-scale models (HSPF). We also found that the representation of time in a model constrains the level of integration of the effects of agricultural practices on processes (Section 3.1). Finally, we found that different models rely on the same method to simulate the effect of an agricultural practice on a process and that only a few methods integrate the practice at level 4 (Sections 3.2, 3.3, and 3.4).

\subsection{Continuous and event models}

Borah and Bera (2003), Quilbé et al. (2006), and Payraudeau and Gregoire (2012) divided catchment scale models into two categories: event models and continuous models. Event models simulate catchment response to a single rainfall event and are thus short-term response models, whereas continuous models simulate rainfall events as well as changes in the catchment between rainfall events. The resulting total simulation period can last from less than 10 years to more than 40 years (Borah and Bera 2004). Our conclusion is that event models (I-pest, I-phyBV, and MHYDAS) do not simulate the 


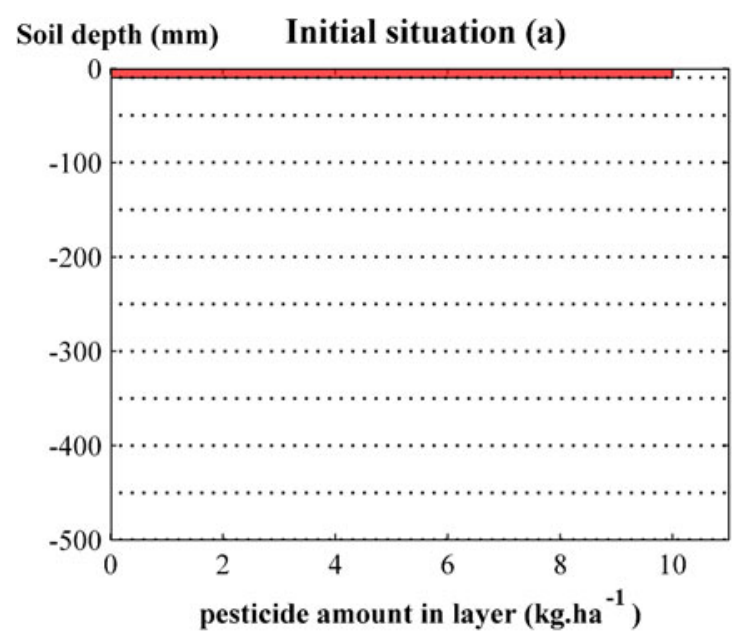

Soil depth (mm) SWAT \& RZWQM (c)

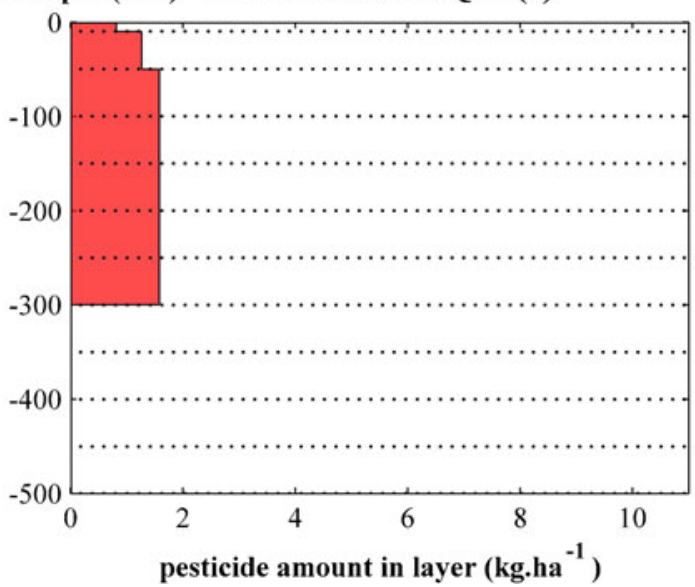

Fig. 4 Comparison of the effects of the tillage algorithms found in models on the vertical distribution of pesticides in the soil profile. Tillage is a moldboard plow operation at $30 \mathrm{~cm}$ depth from an initial situation of $10 \mathrm{~kg} / \mathrm{ha}$ of pesticides applied to the first $1-\mathrm{cm}$ layer of the soil. The soil was represented as having 11 layers and a depth of $50 \mathrm{~cm}$. The first layer was $10 \mathrm{~mm}$ deep, the second $40 \mathrm{~mm}$, and the other eight were each

effects of agricultural practices on environmental characteristics. In such models, the initial values of environmental characteristics have to be estimated or measured prior to the simulation (integration at level 3). For instance, MHYDAS associates soil-saturated hydraulic conductivity values with different cropping system components, such as tilled fields or untilled fields, prior to the calculation (Moussa et al. 2002); I-phyBV indicator values are inferred from MHYDAS simulation results using the Monte Carlo procedure (Wohlfahrt 2008) or expert parameterization based on soil hydraulic conductivity at saturation characteristics (Thiollet-Scholtus 2004). Conversely, the 14 continuous models (annAGNPS, geoPEARL, GLEAMS, HSPF, MACRO, MIKE SHE, PEARL, PestLCI, PRZM, R-pest, RZWQM, SoilFug, and SWAT) make it possible to integrate practices at level 4 as they at least simulate changes in one environmental
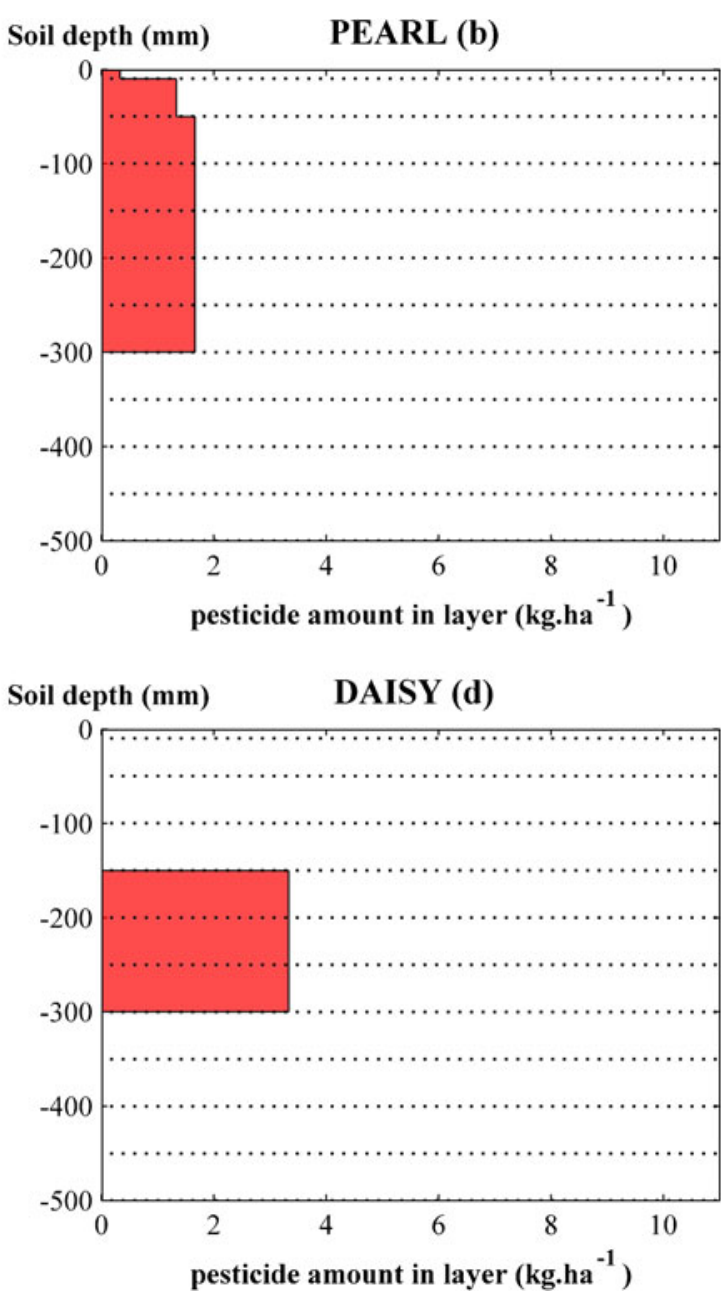

$50 \mathrm{~mm}$ deep. a Initial situation or models without tillage algorithm. b Pesticide Emission Assessment at Regional and Local scales (PEARL) tillage algorithm. c Soil and Water Assessment Tool (SWAT) and Root Zone Water Quality Model ( $R Z W Q M)$ algorithm, the mixing efficiency parameter is set to 0.95 as indicated in the documentation of the models. $d$ DAISY (not an acronym) algorithm

characteristic (crop cover). However, this is not the case for all processes, as only six models integrate the effect of tillage on runoff by incorporating crop residues at level 4 (annAGNPS, GLEAMS, PRZM, RZWQM, R-pest, and SWAT) and only five integrate the effect of tillage on erosion by modifying the erodibility characteristic at level 4 (annAGNPS, GLEAMS, PRZM, R-pest, and SWAT) (Table 4).

\subsection{Tillage and runoff}

Three methods are used to produce runoff in models. The first is the curve number method (USDA 1986). The curve number is a lumped parameter that includes the effect of land use and surface conditions, among other characteristics (Ponce and Hawkins 1996). Surface conditions include the effects of 
ground cover. GLEAMS, SWAT, annAGNPS, and PRZM use a curve number parameter to simulate runoff. The curve numbers are estimated using the values available in USDA (1986), which were recently updated (USDA 2012) and include the effects of both soil hydraulic properties and ground cover (level 4).

The second is the EPIC method. RZWQM and MACRO solve Richards' equation to produce runoff. More information on methods used to simulate water and pollutant flows in soil macropores is available in Simunek et al. (2003) and in Köhne et al. (2009a, b). RZWQM and MACRO require soil hydraulic properties and use the same algorithm to estimate changes in soil hydraulic properties after tillage. Soil hydraulic properties rely on the soil bulk density, which is the result of tillage operations and soil reconsolidation. In both models, the method used to predict soil bulk density after tillage is based on the EPIC model (Williams et al. 1984) which uses a tillage intensity factor and a consolidation bulk density. The EPIC method comes with tillage intensity factors for various tillage tools (Rojas and Ahuja 2000; Williams et al. 1990). The EPIC method is thus level 4 for soil hydraulic properties, but for runoff through ground cover is only level 2 , since ground cover is not represented as affecting runoff. In HSPF, ground cover restricts the velocity of runoff and reduces the total quantity of runoff by allowing more time for infiltration. HSPF has no tillage module (level 3) unless coupled to PRZM (level 4).

The last method comes with R-pest. Runoff is calculated as a function of soil hydraulic properties (soil compaction), tillage direction, and ground cover. All tillage practices have the same effect on the soil compaction indicator and ground cover by decreasing their values to the minimum values ( 0 and $0 \%$ ). Tillage is thus integrated at level 4 but relies on extreme modifications of environmental characteristics.

\subsection{Tillage and erosion}

Models that use the Universal Soil Loss Equation (Wischmeier and Smith 1978) or its derivative, the Revised Universal Soil Loss Equation (Renard et al. 1997) to simulate erosion integrate tillage effects at level 4 . In these methods, two factors of the equation, $C$ and $P$, stand for the effect of the cropping system and the erosion control practices on soil erodibility, respectively. The $C$ factor is modified by tillage practices, whereas the $P$ factor stands for more structural tillage practices (contour tillage, strip cropping). AnnAGNPS, GLEAMS, and PRZM use a surface roughness coefficient, which is modified by tillage, to calculate the $C$ coefficient. Databases that can be used for this calculation are available in Sharpley and Williams (1990), Wischmeier and Smith (1978), or the specific model documentation. The Universal Soil Loss Equation is used by models that use curve numbers to simulate runoff. As for runoff, R-pest integrates the effect of tillage on erosion at level 4 using extreme modifications of soil compaction and soil cover.

MIKE SHE and MHYDAS use physically based methods to represent soil erosion. MHYDAS uses MHYDASEROSION (Gumiere et al. 2010). The MIKE SHE erosion module is based on the European Soil Erosion Model (Morgan et al. 1998). In both models, erosion is presented as being modified by tillage, but there is no module to estimate the effects of tillage on erosion (level 3). Instead, models use calibrated data or measured data on fields that are tilled or not tilled (Gumiere et al. 2010). In MHYDAS, the soil cover is not represented, but its effect on erosion can be taken into account using the Manning roughness coefficient. MIKE SHE reduces rainfall energy by crop canopy interception.

\subsection{Data requirements}

Despite the large number of studies reviewed by Alletto et al. (2010) that report the effects of tillage on the fate of pesticides, tillage integration at level 4 is limited to global trends of cropping systems such as conventional tillage and conservation tillage. This confirms the lack of available knowledge to parameterize the effects of tillage on pesticide transfers. For instance, the curve number and the Universal Soil Loss Equation can be used to estimate the effect of conventional and conservation tillage on runoff and erosion, respectively. Each tillage modality works with two possible tillage directions: straight rows or contouring. Other authors integrate tillage at level 4 using only one tillage modality leading to modifications of environmental characteristic to extreme values (R-pest). Other methods with the highest tillage resolution (choice of tool) such as the EPIC method were perhaps not integrated in the catchment scale models because these models focus on the effect of tillage on runoff using only soil hydraulic properties and do not consider the other effects of tillage on runoff (ground cover) or on other processes (erosion).

\section{Pesticide distribution}

When pesticides are applied to fields, the dose is split between the different environmental compartments (plant, soil, air, mulch). The distribution of pesticides in the field influences whether they are subject to transfer and degradation processes such as washoff, runoff, volatilization, leaching, photodegradation, bacterial metabolism, and hydrolysis (Barriuso 2004). For instance, pesticides that are incorporated into the soil are less exposed to volatilization and runoff than pesticides applied on the surface of the soil (Larson et al. 1995). Pesticides applied on plants are subject to washoff, photodegradation, and plant absorption, whereas pesticides in the soil are not (Calvet et al. 2005; Galiulin et al. 2002; Norris 1974). Pesticide 
distribution at field scale determines the pathways of the pesticide to the catchment outlet. For instance, Charlier et al. (2009) showed that, in the specific case of a catchment with shallow groundwater connected to surface water, pesticide transfers by runoff cause peaks of high pesticide concentrations in the stream, whereas shallow groundwater flows buffer pesticide concentrations by diluting and spreading pesticides over time leading to chronic contamination of the stream. To illustrate the potential effects of model structures and model algorithms on cropping systems assessment, we present practices that directly affect the distribution of pesticides in fields: tillage (Section 4.1) and pesticide applications (Section 4.2).

\subsection{Tillage effects}

To simulate the redistribution of chemicals during tillage, models have to use a layered representation of the soil. Seven models do not represent the effect of tillage on pesticide redistribution in the soil (annAGNPS, GLEAMS, I-pest, IphyBV, PestLCI, R-pest, and SoilFug). Among them, four models (I-pest, I-phyBV, R-pest, and SoilFug) have no layered representation of the soil. These models cannot represent the vertical heterogeneity of soil pesticide contents. AnnAGNPS, GLEAMS, and PestLCI have a layered soil representation but either lack a module for representing soil mixing by tillage (PestLCI) or they have one for nutrients but not for pesticides (annAGNPS and GLEAMS).

PEARL, SWAT, RZWQM, MACRO, and PRZM have a pesticide mixing module. The simplest module for tillage mixing is the one in PEARL. The module mixes the amount of pesticides uniformly throughout the tillage depth (Fig. 4b). Only tillage depth is needed in this case. The SWAT and RZWQM mixing modules (Fig. 4c) require two parameters to estimate chemical mixing in soil layers: depth and mixing efficiency. The efficiency is the fraction of pesticide mixed uniformly in the tilled layers. When coupled to the DAISY field model, the MIKE SHE model has a mixing module with two basic actions: mix and swap. With the mix effect, pesticides are averaged throughout the tillage depth. Swap simulates the inversion effect of tillage. When swap is enabled, DAISY considers two equal sub-layers that are swapped around by tillage after being mixed separately (Fig. 4d). PRZM and MACRO consider the effect of tillage on pesticide distribution in the soil only if tillage is performed on the same day as pesticide application. In these models, subsequent tillage operations have no effect on pesticide distribution in soil layers. Suarez (2005) gives the links between tillage practices and the different tillage algorithms used by these two models.

Tillage algorithms result in different vertical distributions of pesticides, making different amounts of pesticide available for the transfer processes such as runoff and percolation in the soil. Here we consider that only pesticides in the top layer are available for runoff. After the operation presented in Fig. 4, the soil surface holds $0.33 \mathrm{~kg} \mathrm{ha}^{-1}$ of pesticide with PEARL. The RZWQM and SWAT algorithm resulted in more than twice this amount $\left(0.81 \mathrm{~kg} \mathrm{ha}^{-1}\right)$ at the soil surface whereas the DAISY algorithm does not make any pesticides available to the soil surface $\left(0 \mathrm{~kg} \mathrm{ha}^{-1}\right)$. Models with no tillage algorithm for pesticides assume the total amount of pesticides applied $\left(10 \mathrm{~kg} \mathrm{ha}^{-1}\right)$ is available for runoff. These differences can lead to simulations of contrasting behaviors of pesticides in the catchment by modifying the transfer pathways.

\subsection{Pesticide application practices}

Pesticide application practices lead to several different distributions of the pesticides applied to the different compartments such as crops, cover crops, weeds, and residues as well as their distribution in the soil profile. In the models we reviewed, we identified different height representations of pesticide application practices affecting pesticide distribution in environmental compartments (Table 5).

Above canopy broadcast application is a practice included in all continuous models as well as in indicators. It stands for spraying pesticide uniformly above the crop canopy. In models, the amount of pesticide applied is linearly intercepted by the crop on the basis of crop coverage with the remaining fraction reaching compartments located under the crop, i.e., the mulch and the soil. In GLEAMS, the intercepted fraction has to be indicated manually. PRZM and MACRO account for a linear or an exponential filtration by crop canopy. Among the models reviewed, only RZWQM simulates the interception of pesticides by a mulch of crop residues before they reach the soil (Table 5).

Soil broadcast means the pesticide is directly applied on the soil. In models, this is represented by directly adding nondrifted pesticides to the soil. In this case, no interception by any environmental compartments other than soil is simulated. If soil is layered, pesticide is added to the first centimeter of soil (GLEAMS, annAGNPS, and RZWQM); pesticide is distributed to $4 \mathrm{~cm}$, linearly decreasing with depth (PRZM and MACRO); or pesticide is added to the top computation layer (PEARL and geoPEARL). If soil is not layered, pesticide is homogenously mixed in the soil.

Foliar application means the pesticide is applied to the leaves using manual or vertical mechanical pulverization. In models, it is simulated by adding non-drifted pesticides to the crop compartment only.

The use of slow release (microencapsulated) pesticide formulations (Shasha et al. 1976; Sinclair 1973) is simulated only in RZWQM using a time-dependant amount of pesticide available from an initial stock.

Injection in the soil is the application of the pesticide at a certain depth in the soil with or without pressure (All and Dutcher 1977). It is usually used for fumigation purposes. In 
Table 5 Pesticide application practices available in models

\begin{tabular}{|c|c|c|c|c|c|c|c|c|}
\hline Models & $\begin{array}{l}\text { Above canopy } \\
\text { broadcast }\end{array}$ & $\begin{array}{l}\text { Soil } \\
\text { broadcast }\end{array}$ & $\begin{array}{l}\text { Incorporation } \\
\text { with tillage }\end{array}$ & $\begin{array}{l}\text { Foliar } \\
\text { application }\end{array}$ & $\begin{array}{l}\text { Application in } \\
\text { irrigation water }\end{array}$ & $\begin{array}{l}\text { Slow release } \\
\text { application }\end{array}$ & $\begin{array}{l}\text { Injection } \\
\text { in soil }\end{array}$ & $\begin{array}{l}\text { Band or localized } \\
\text { application }\end{array}$ \\
\hline $\operatorname{annAGNPS}$ & $\mathbf{X}$ & $\mathbf{X}$ & $\mathbf{X}$ & $\mathbf{X}$ & - & - & - & - \\
\hline geoPEARL & $\mathbf{X}$ & $\mathbf{X}$ & $\mathbf{X}$ & $\mathbf{X}$ & - & - & $\mathbf{X}$ & - \\
\hline GLEAMS & $X$ & $X$ & $X$ & $X$ & $X$ & - & $X$ & $X$ \\
\hline HSPF & \multicolumn{8}{|c|}{ See PRZM via PZ2HSPF } \\
\hline I-pest & $X$ & - & $X$ & - & - & - & - & - \\
\hline I-phyBV & $\mathbf{X}$ & $\mathbf{X}$ & $\mathbf{X}$ & - & - & - & $\mathbf{X}$ & - \\
\hline$M A C R O$ & $X$ & $X$ & $X$ & - & - & - & $X$ & $X$ \\
\hline MHYDAS & \multicolumn{8}{|c|}{ Not documented } \\
\hline MIKE SHE & $\mathbf{X}^{\mathbf{b}}$ & - & - & - & - & - & - & - \\
\hline PEARL & $X$ & $X$ & $X$ & $X$ & - & - & $X$ & - \\
\hline PestLCI & $X$ & - & - & - & - & - & - & - \\
\hline PRZM & $X$ & $X$ & $X$ & - & - & - & $X$ & $X$ \\
\hline$R$-pest & - & $X$ & - & - & - & - & - & - \\
\hline$R Z W Q M$ & $X^{a}$ & $X$ & $X$ & $X$ & $X$ & $X$ & $X$ & - \\
\hline SoilFug & \multicolumn{8}{|c|}{ Not documented } \\
\hline SWAT & $\mathbf{X}$ & - & $\mathbf{X}^{\mathbf{c}}$ & - & - & - & - & - \\
\hline
\end{tabular}

Catchment scale models are in bold; field-scale models are in italics

$X$ taken into account in the model, - not taken into account in the model or undocumented, Above canopy broadcast the pesticide is sprayed uniformly above the crop canopy, Soil broadcast the pesticide is directly applied on the soil, Foliar application the pesticide is applied to the leaves using manual or vertical mechanical pulverization, Application in irrigation water the pesticide is diluted in irrigation water, Slow release application the formulation of the pesticide results in a slow release of the pesticide in or on soil, Injection in soil the pesticide is applied at a certain depth in the soil, Band or localized application the pesticide is applied in parallel bands or in specific places such as on or between the rows

${ }^{a}$ Pesticide interception by crop residues

${ }^{\mathrm{b}}$ Using DAISY as field model

${ }^{\mathrm{c}}$ Only after an above canopy broadcast application

models, it is simulated by concentrating pesticides at a specific depth in the soil.

Band application and localized application means the pesticide is applied in parallel bands or in specific places such as on or between the rows. In GLEAMS, band application decreases the total amount of pesticide applied to fields compared to a broadcast application (Knisel et al. 1995). It accounts for the ratio of the treated area and the total area of the field. In MACRO and PRZM, however, localized pesticide applications attracted our attention. Indeed, the horizontal distribution of pesticides on fields resulting from localized applications is represented by a vertical depth-dependant distribution of pesticide in the soil profile (Suarez 2005). These two models use their conceptual vertical discretization to represent the effect of practices leading to heterogeneous horizontal distribution of pesticides in the soil.

Even if an application method is taken into account, its effect on pesticide transfers relies on the conceptual compartmentalization of the model. For instance, RZWQM is the only model we reviewed in which mulch intercepts pesticides. The other models do not simulate mulch or do not simulate pesticide interception by mulch (Tables 4 and 5). This impacts the whole simulation of pesticide fate as the pesticides in these different environmental compartments are not subject to the same processes.

\section{Innovative practices: ground cover management}

Ground cover is a key environmental characteristic affecting pesticide transfer processes such as runoff, volatilization, and erosion (Alletto et al. 2010; Antonious and Byers 1997; Bartley et al. 2006; Foltz 2012; Gish et al. 1995). Ground cover can take the form of pervious or impervious mulches, and these have contrasting effects on pesticide transfers. Pervious mulch made of dead or living plants reduces runoff (Dabney 1998; Findeling et al. 2003) whereas impervious mulches (such as plastic mulch) favor runoff (Rice et al. 2001). Pervious mulch results from a combination of practices and processes such as planting a crop and a cover crop, the growth and development of both along with spontaneous weeds. Weeding or mowing transforms living mulch into dead 
mulch if not removed. Tillage incorporates mulches into the soil with varying degrees of efficiency. To assess whether the models simulate innovative cropping systems and compare them to conventional ones, we analyzed the effects of practices affecting ground cover in both catchment and field-scale models (Table 4): tillage (Section 5.1), plastic mulching (Section 5.2), "dead" mulching (Section 5.3), and cover cropping and intercropping (Section 5.4).

\subsection{Tillage and ground cover}

Ground cover is directly affected by tillage, by the burying of plants and plant residues. In SWAT, MIKE SHE-DAISY, and RZWQM, the effect of tillage on ground cover is simulated in the same way as chemical redistribution in the soil. The mixing module is used to estimate soil cover as a result of biomass redistribution in the soil. GLEAMS, annAGNPS, and PRZM use a residue incorporation efficiency parameter to determine the percentage of residue and plant material incorporated into the soil and left on the surface after a tillage operation (Knisel and Walter 1980; Knisel and Walter 1993). R-pest has only one tillage operation in its database, and it decreases soil cover by weeds and residues to $0 \%$ (Tixier 2004). MACRO, PEARL, PestLCI, and SoilFug do not simulate residues on the soil surface. MIKE SHE or HSPF can take the effect of tillage on ground cover into account by bridging pesticide transfer models at the field scale to these two catchment scale models. The effect of tillage on ground cover is simulated by half the models reviewed (Table 4), depending on the modelers' objectives.

\subsection{Plastic mulch}

The most widely used impervious mulch is plastic, and its use has increased dramatically in the last 10 years (Kasirajan and Ngouajio 2012). It is mainly used for weed control in vegetable crops (Rice et al. 2001) and pineapple (Dusek et al. 2010). Impervious mulch favors runoff from covered fields. Due to its high cost, it is used for small area with high-income crops. However, none of the models we reviewed had available parameters or modules to simulate the effects of impervious mulch on the water budget or on the fate of pesticides. However, Dietrich and Gallagher (2002) showed extremely high concentrations of pesticides $\left(>100 \mu \mathrm{g} \mathrm{L}^{-1}\right)$ in runoff water from tomato fields covered with plastic mulch which might be explained by the fraction of pesticide washed off leaves but not intercepted by the soil during runoff. In the case of pesticides that only very weakly bind to plastic, runoff can be enriched by the fraction of pesticides that are deposited on the mulch during application. For this reason, plastic mulching has been described as favoring pesticide transfers. Nevertheless, such effects are not included in pesticide transfer models either at the catchment or field scale.

\subsection{Dead mulch}

Mowing, clearing, pruning, harvesting, and weeding remove plant biomass from a living plant whether it be a crop, a cover crop, or a weed. The biomass can either be removed from the field or feed the pool of residues that remains on the soil surface. In the first case, the overall soil cover is depreciated, whereas in the second case, living mulch is converted into dead mulch and the plant residues undergo degradation (Raphael et al. 2012; Ripoche et al. 2008). GLEAMS, RZWQM, R-pest, PRZM, SWAT, annAGNPS, DAISY, and HSPF can simulate crop residues (Table 4), but not all models simulate the impact of a crop residue cover on pesticide transfers. For instance, in DAISY for MIKE SHE, crop residues are simulated to estimate changes in the organic matter pool but were not found to have an effect on hydrologic or pesticide transfer processes through ground cover. R-pest and SWAT are the only two models that simulate the generation of dead mulch by practices other than harvesting. SWAT, however, has only a partial support for the different practices. They can be simulated by combinations of simpler unitary operations with overridden parameters. Mulching crop residues during the crop cycle is not directly considered in the models (except with R-pest), thus confirming a lack in the representation of agricultural practices associated with ground cover in pesticide transfer models at both the field and catchment scales.

\subsection{Crops, weeds, and cover crops}

Ground cover is affected by crops, weeds, and cover crops. Except I-pest, I-phyBV, and MHYDAS, all the models reviewed simulate the growth of at least one crop associated with agricultural practices.

Mixing crops has potentially beneficial effects on environmental impacts and increases productivity (Malézieux et al. 2009). To integrate these effects of mixing crops, a model is needed that simulates the growth of several crops at the same time as well as their interactions. However, mixtures of crops and crop-weed associations are not widely represented in most crop models (Malézieux et al. 2009). Among catchment scale models, only SWAT can simulate mixing crops (Table 4). R-pest coupled with SIMBA enables a simple dynamic simulation of ground cover by weed growth under a banana canopy. A more complex support to simulate the growth of a cover crop has recently been developed for SIMBA (Tixier et al. 2011). I-pest and I-phyBV make it possible to indicate percentage soil cover by weeds, cover crops, and associated crops but do not simulate their growth. A major limitation of the pesticide transfer models at the field and catchment scales is that their crop models do not simulate mixed cropping, cover cropping, or weed management. 


\section{Upscaling practices}

\subsection{Space representation}

Three classifications are usually given for spatial representation in catchment scale models: (a) lumped models, (b) distributed models, and (c) semi-distributed models (Beckers and Degré 2011; Gárfias et al. 1996). Lumped models are unable to account for the position of cropping systems within the watershed. However, they can be used on small catchments to represent pollutant transfers in groundwater using residence time distribution in the aquifers (Farlin et al. 2013). Distributed models split the catchment into units of fixed size usually by using a square grid (MIKE SHE, AGNPS) or a triangular grid (Julien et al. 1995). Spatial representation in distributed models is a complex affair concerning landscape elements that are smaller than the grid resolution. This is usually the case of linear entities, such as roads and ditches, as well as small areal entities such as buffer zones which have been shown to affect flows in watersheds (van Dijk et al. 1996; Jones et al. 2000). Semi-distributed models represent a watershed as a combination of lumped units usually called hydrologic response units or homogenous land units. These units are to be considered homogeneous with respect to their environmental characteristics (usually slope, soil type, and cropping system). In fact, and especially when modeling large watersheds, homogeneous units usually include a variety of cropping systems, leading to drastic simplifications in cropping system diversity within the homogeneous units. The difference between distributed and semi-distributed models is fuzzy as a distributed model grid considers lumped parameters. The distributed characteristic of a model depends on the ratio of the grid size to the size of the watershed (Bathurst 1986). This determines whether the model can separate agricultural fields or combines cropping system diversity under a unique value.

Over and above the size of the units and the regularity of the grids of distributed and semi-distributed models, the most astonishing difference in spatial representations in catchment scale models is related to the interactions between spatial units ("the interacting unit models"). Four of the models (HSPF, MIKE SHE, MHYDAS, I-phyBV) we reviewed simulate spatial interactions: Pesticides and water flows produced by a spatial unit enter the next spatial unit in the flow path and are subject to the processes that occur in the neighboring spatial unit. The discretization method proposed by Lagacherie et al. (2010) in Geo-MHYDAS uses an irregular grid but enables interactions between spatial units such as inflow interception by defining a topological organization of units within catchments. Such advances make it possible to generate space discretization to account for different types of spatial units (channels and fields for instance) while allowing spatial interaction between units on pesticide flows.

\subsection{Drift modeling}

The direct loss of pesticides during their application is called drift. This loss can pollute the vicinity of the field including streams, grass strips, or other fields. Application methods and the height of pulverization are the main factors that determine the amount of pesticides that drift during application taken into account by models (Birkved and Hauschild 2006; Wauchope et al. 2004; van der Werf and Zimmer 1998). Models can be classified in three groups depending on the way they handle drift (Table 4). Drifted pesticides may be represented as leaving the system (SWAT, GLEAMS, RZWQM, PestLCI, PRZM, and HSPF with the PZ2HSPF bridge), as being re-deposited as a function of distance from the field (I-pest and I-phyBV), or may simply not be taken into account (R-pest, annAGNPS, MIKE SHE, SoilFug). We found no information in MHYDAS or PEARL even though the drift process is mentioned in PEARL documentation (Leistra et al. 2001). Models that consider drift to leave the system use a pesticide application efficiency factor. In these models, the efficiency of pesticide application is the fraction of pesticides reaching the field, with the drifted part being lost. Values proposed for estimating drifted fractions in models that do not consider redeposition are substantial. Wauchope et al. (2004) estimate drift to range from 40 to $55 \%$ of the amount of pesticides applied. Such values are confirmed by values ranging from 20 to $50 \%$ of the applied dose (Maybank et al. 1978; Ravier et al. 2005).

At the catchment scale, the objective of calculating drift is estimating pesticide deposition on surrounding fields and rivers. Models considering drift deposition use the Ganzelmeier estimation method (Ganzelmeier et al. 1995) but only account for redeposition in rivers. Estimation of pesticide deposition is given as a function of distance from the field, the application technique, and the height of application. I-pest and I-phyBV use this method to estimate pesticide drift reaching the river (Thiollet-Scholtus 2004; van der Werf and Zimmer 1998). More recently, SWAT was adapted by Holvoet et al. (2008) to deal with direct losses and redeposition during pesticide applications also using the Ganzelmeier method. However, this has not yet been incorporated in the current version. The other catchment models fail to use the drift outputs from the field-scale models as inputs, e.g., pesticide redeposition, when modeling catchment processes. This shows that the change in scale needs to be better addressed in catchment models. Drift redeposition in catchments models will have to account for the organization and characteristics of the landscape when assessing the effects of drift on streams. Trees or other tall crops acting as buffers are not taken into consideration by the Ganzelmeier method in drift interception even though they can intercept a significant part of pesticide drift (Hewitt 2001; de Schampheleire et al. 2008). In their literature review, Ucar and Hall (2001) reported a lack of standard methodology to assess the effect of physical barriers on pesticide drift. Drift models have been developed to estimate the contamination of unwanted 
targets by pesticides (Ellis and Miller 2010; Gil and Sinfort 2005). One of the next moves in catchment scale modeling should be to simplify and integrate landscape scale drift models.

Drift is the most weighted parameter determining river contamination risk in I-pest even for orchard systems. This is not in accordance with the lower influence of drift than of runoff in river contamination found in orchard systems (Schulz 2001) or with authors who report little influence of drift on stream water quality in open cereal cropping areas (Kreuger 1998). The I-pest indicator is considered at its unfavorable value when the drifted fraction reaching the river is higher than an arbitrarily selected value of $1 \%$ (van der Werf and Zimmer 1998). To better account for the effect of drift on surface water contamination, the stream discharge — or at least the length and the width of the stream - should be taken into consideration.

\section{Practices at the catchment scale}

Catchment practices are structures that are integrated in the landscape. They modify the behavior of pesticides before they reach the catchment outlet. In model documentation, we found information on buffer zones, drainage ditches and waterways, water bodies (ponds), tile drainage, and irrigation practices (Table 6). In the following sections, we show that the management of catchment structures needs to be better taken into account in models. We also found that not all models simulate the remobilization of pesticides intercepted by catchment structures. To illustrate these results, we compare the effects of drainage ditches, grassed waterways (Section 7.1) and buffer zone areas (Section 7.2) on pesticide transfers in the different models.

\subsection{Ditches and waterways}

The objectives of creating drainage ditches and grassed waterways are to intercept runoff and to favor water and pesticide infiltration while routing flow to the outlet. The vegetative cover of ditches and waterways is a key factor in pesticide interception because plants retain pesticides (Moore et al. 2001, 2011). On the contrary, non-vegetated ditches and gullies favor quick pesticide routing to the permanent hydrographic network, leading to pesticide contamination peaks.

Table 6 Catchment practices interacting with pesticide transfers available in models

\begin{tabular}{|c|c|c|c|c|c|c|c|}
\hline \multirow[t]{2}{*}{ Models } & \multicolumn{4}{|c|}{ Catchment practices } & \multicolumn{3}{|l|}{ Irrigation } \\
\hline & Buffer zone & Drainage ditches & Waterbodies & Tile drainage & Irrigation & Chemicals in irrigation water & Water removal from source \\
\hline annAGNPS & $\mathbf{X}^{\mathbf{b}}$ & $\mathbf{X}$ & $\mathbf{X}$ & $\mathbf{X}$ & $\mathbf{X}$ & $\mathbf{X}$ & - \\
\hline geoPEARL & - & $\mathbf{X}$ & - & $\mathbf{X}$ & $\mathbf{X}$ & $\mathbf{X}$ & - \\
\hline GLEAMS & - & - & - & - & $X$ & - & - \\
\hline HSPF & $\mathbf{X}$ & $\mathbf{X}$ & $\mathbf{X}$ & - & $\mathbf{X}^{\mathrm{e}}$ & - & - \\
\hline I-pest & - & - & - & - & - & - & - \\
\hline I-phyBV & $\mathbf{X}$ & $\mathbf{X}$ & - & $\mathbf{X}$ & - & - & - \\
\hline MACRO & - & - & - & $X$ & $X$ & - & - \\
\hline MHYDAS & $\mathbf{X}$ & $\mathbf{X}^{\mathbf{c}}$ & - & $\mathbf{X}^{\mathbf{c}}$ & - & - & - \\
\hline MIKE SHE & $\mathbf{X}$ & $\mathbf{X}$ & $X^{\mathbf{d}}$ & $\mathbf{X}$ & $\mathbf{X}$ & - & $\mathbf{X}$ \\
\hline PEARL & - & $X$ & - & $X$ & $X$ & $X$ & - \\
\hline PestLCI & - & - & - & - & $X$ & - & - \\
\hline PRZM & $X^{a}$ & $X$ & - & - & $X$ & - & - \\
\hline$R$-pest & - & - & - & - & $X$ & - & - \\
\hline$R Z W Q M$ & - & - & - & $X$ & $X$ & - & - \\
\hline SoilFug & - & - & - & - & $\mathbf{X}$ & - & - \\
\hline SWAT & $\mathbf{X}$ & $\mathbf{X}$ & $\mathbf{X}$ & $\mathbf{X}$ & $\mathbf{X}$ & $\mathbf{X}$ & $\mathbf{X}$ \\
\hline
\end{tabular}

Catchment scale models are in bold; field-scale models are in italics

$X$ taken into account in the model, - not taken into account in the model or undocumented

${ }^{\text {a } U s i n g ~ P R Z M-B U F F ~}$

${ }^{\mathrm{b}}$ Coupling with the Riparian Ecosystem Management Model

${ }^{\mathrm{c}}$ Using MHYDAS-DRAIN

${ }^{\mathrm{d}}$ Using MIKE 11

${ }^{\mathrm{e}}$ Using PRZM as field model 
Three models use drainage ditches to simulate the routing of excess water to the hydrographic network only (geoPEARL, MIKE SHE, and MHYDAS). MHYDAS uses MHYDAS-DRAIN to represent ditches (Tiemeyer et al. 2007). The module has been used to test the effect of ditch networks on hydrology (flow routing and reinfiltration) but not on pesticide behavior (Levavasseur et al. 2012). None of the three models simulate the effect of a grassed ditch on pesticide removal from water and sediment flow. In these models, groundwater drainage is usually associated with tile drainage. As a result, in all three models, ditches favor fast pesticide flows to the river network. Models should be selected knowing that not all models that simulate ditches were designed to simulate pesticide interception by ditches.

Ditches and waterways in SWAT, annAGNPS, HSPF, and I-phyBV remove pesticides. In annAGNPS and HSPF, the effect of grassed waterways is parameterized using the channel module (LimnoTech 2010; Mohamoud et al. 2010). All four models make it possible to specify the length of ditches to assess their effect on pesticide removal. The width (HSPF, SWAT), the shape (HSPF), and the cover (HSPF, I-phyBV, and SWAT) of the waterways are used to determine pesticide interception effectiveness. Nevertheless, we found no modules that accounted for the management of ditches or waterways in the models or for the natural evolution of their ground cover.

\subsection{Buffer zones}

Buffer zone is a generic term to define non-channelized areas that intercept runoff, sediments, and pesticides due to a high vegetative or dead mulch coverage (Barling and Moore 1994). These zones are assumed to produce very little runoff and erosion. Three main types of buffer zones exist: buffer grassed strips, hedges, and riparian zones. Even though any correctly managed land can act as a buffer zone, these three zones intercept runoff, pesticides, and sediments (Campbell et al. 2004; Carluer et al. 2008; Lacas et al. 2005, 2012; Lin et al. 2002; Madrigal et al. 2002; Madrigal 2004; Passeport et al. 2013; Tortrat 2005). Except geoPEARL and SoilFug, all the catchment scale models we reviewed have been used to simulate the effect of buffer zones on pesticides, runoff, or erosion. While the AGNPS model (event model used as a basis of annAGNPS) simulates the buffer zone effects of sediments and attached pesticides (Vennix and Northcott 2004), annAGNPS does not. Bridging annAGNPS with the Riparian Ecosystem Management Model (REMM) is a way to simulate the effect of buffer zones (Yuan et al. 2007). AnnAGNPS-REMM simulates only riparian zones, which limits the spatial distribution of buffer zones in the catchment. Among pesticide transfer models at the field scale, only PRZM simulates buffer zones using the PRZM-BUFF model (Winchell and Estes 2009).
HSPF, MIKE SHE, I-phyBV, and MHYDAS are interacting unit models. Buffer zones are simulated by the generic field module of the model. In this case, any piece of land is potentially a pesticide interceptor and emitter at the same time. The size of buffer zones is constrained by the minimum size of the unit area accepted by the model. Water and pollutant interception depends on environmental characteristics which can be modified by the practices available in the model. In SWAT, no interaction between hydrologic response units can be simulated. Buffer zones are part of the hydrologic response units; they interact with the runoff generated by the unit, but not with runoff generated by upland units. In SWAT, a buffer zone can only intercept flows generated by one hydrologic response unit while models that simulate inflows in each spatial unit account for larger contributing areas corresponding to the watershed whose outlet is the buffer zone.

In continuous models, two contrasting representations of pesticide interception by buffer zones exist. HSPF and MIKE SHE represent conservative pesticide interception, which means that the next rainfall event remobilizes previously intercepted pesticides. In contrast, SWAT pesticide interception by buffer zones is not conservative. The removed fraction leaves the system. This is not in agreement with Lacas et al. (2005) and Barling and Moore (1994), who report that pesticides intercepted by buffer zones move to the subsurface or are desorbed from the soil surface. Thus, when simulating the effects of buffer zones, users must carefully check that the model's assumption will not lead to an underestimation of pesticide pollution at the catchment outlet.

\section{Conclusions}

This review helped identify the improvements required to better account for the effects of agricultural practices on pesticide transfers. We also provide some recommendations to help model users select an appropriate model depending on their objectives:

1. The change in scale is poorly addressed, as representations of pesticide applications on drift kept the original field-scale representation in all models except I-phyBV. Drift redeposition has been addressed in SWAT but is not yet included in the current version of the model. Drift needs to be better integrated in catchment models.

2. The integration of innovative practices is a necessary step forward in field and catchment models to ensure models are capable of assessing innovative cropping systems. Plastic mulches and associated cover cropping practices are already integrated in crop models such as STICS (Brisson et al. 2009), the cropping system representations of which may serve their improvements in pesticide transfer models at the field and catchment scales. 
3. Using the conceptual framework proposed in this article, model users and developers will be aware of both the effects of practices represented by models and of those which are not. Its use will make descriptions of the effects of practices clearer, which, in turn, will make the selection and development of models easier.

4. A practice library compatible with the different models needs to be developed. This library should include empirical data and equations to simulate the effects of practices on environmental characteristics. Relationships between the parameters of the main methods used to simulate the effects of practices on environmental characteristics will become apparent.

5. Users should only select models that represent catchment structures that are not conservative in the knowledge they may underestimate pesticide transfers.

6. Model structure influences how pesticides are distributed and subjected to transfers processes. Model users and modelers must think carefully about the conceptual environmental compartments needed to simulate the effects of practices together with processes.

7. Semi-distributed models should make it possible for users to enable topological representations of catchments and allow flow interactions and transfers between spatial units. In some place, such interactions might be significant.

8. Natural changes in the vegetated cover of catchment structures (buffer strips, ditches), as well as the effects of management practices on such structures need to be better addressed in catchment models.

9. The results of simulations made with models using the same practice data need to be compared. It is important to check whether (1) pesticide emissions at field borders vary significantly among models, (2) models with better levels of integration of the effects of tillage and mulching better simulate pesticides transfers, and (3) the spatial representation of the organization of the catchment affects contamination by pesticides at the outlet of the catchment. This will highlight the strengths and weaknesses of catchment scale models in assessing the effects of practices on pesticide transfers.

Acknowledgments This work is part of a Ph.D. thesis funded by Cirad, the European Regional Development Fund of Martinique, the Martinique French Water Office (O.D.E.), and the French Ministry of Overseas (M.O.M.). We thank the anonymous reviewers who helped improve the quality of the manuscript.

\section{References}

Abbott MB, Bathurst JC, Cunge JA, O'Connell PE, Rasmussen J (1986a) An introduction to the European Hydrological System - Systeme Hydrologique Europeen, "SHE", 1: history and philosophy of a physically-based, distributed modelling system. J Hydrol 87:4559. doi:10.1016/0022-1694(86)90114-9

Abbott MB, Bathurst JC, Cunge JA, O'Connell PE, Rasmussen J (1986b) An introduction to the European Hydrological System-Systeme Hydrologique Europeen, "SHE", 2: structure of a physically-based, distributed modelling system. J Hydrol 87:61-77. doi:10.1016/ 0022-1694(86)90115-0

Abrahamsen P, Hansen S (2000) Daisy: an open soil-crop-atmosphere system model. Environ Model Softw 15:313-330. doi:10.1016/ S1364-8152(00)00003-7

Ahuja L, Rojas KW, Hanson JD, Shaffer MJ, Ma L (2000) Root Zone Water Quality Model: modelling management effects on water quality and crop production. Water Resources, Littleton

All JN, Dutcher JD (1977) Subsurface and surface insecticide applications to control subterranean larvae of the grape root borer. J Econ Entomol 70:649-652

Alletto L, Coquet Y, Benoit P, Heddadj D, Barriuso E (2010) Tillage management effects on pesticide fate in soils. A review. Agron Sustain Dev 30:367-400. doi:10.1051/agro/2009018

Altieri MA (1995) Agroecology: the science of sustainable agriculture. Westview, Boulder

Altieri MA, Nicholls CI (2000) Applying agroecological concepts to development of ecologically based pest management strategies. In: National Research Council (ed) Professional societies and ecologically based pest management: proceedings of a workshop. National Academies, Washington, DC, pp 14-19

Antonious GF, Byers ME (1997) Fate and movement of endosulfan under field conditions. Environ Toxicol Chem 16:644-649. doi:10.1002/ etc. 5620160407

Arabi M, Govindaraju RS, Hantush MM (2007) A probabilistic approach for analysis of uncertainty in the evaluation of watershed management practices. J Hydrol 333:459-471. doi:10.1016/j.jhydrol.2006.09.012

Arabi M, Frankenberger JR, Engel BA, Arnold JG (2008) Representation of agricultural conservation practices with SWAT. Hydrol Process 22:3042-3055. doi:10.1002/hyp.6890

Arnold JG, Srinivasan R, Muttiah RS, Williams JR (1998) Large area hydrologic modeling and assessment part I: model development. J Am Water Resour Assoc 34:73-89. doi:10.1111/j.1752-1688.1998. tb05961.x

Arnold JG, Kiniry JR, Srinivasan R, Williams JR, Haney EB, Neitsch SL (2011) Soil and Water Assessment Tool-input/output file documentation-version 2009. Texas Water Resources Institute, College Station

Barling R, Moore I (1994) Role of buffer strips in management of waterway pollution: a review. Environ Manag 18:543-558. doi:10. 1007/BF02400858

Barra R, Vighi M, Di Guardo A (1995) Prediction of surface water input of chloridazon and chlorpyrifos from an agricultural watershed in Chile. Chemosphere 30:485-500. doi:10.1016/0045-6535(94)00412-N

Barra R, Vighi M, Maffioli G, Di Guardo A, Ferrario P (2000) Coupling SoilFug model and GIS for predicting pesticide pollution of surface water at watershed level. Environ Sci Technol 34:4425-4433. doi:10.1021/es000986c

Barreteau O, Richard-Ferroudji A, Garin P (2008) Des outils et méthodes en appui à la gestion de l'eau par bassin versant. Houille Blanche 6:48-55. doi:10.1051/lhb:2008071

Barriuso E (2004) Estimation des risques environnementaux des pesticides. INRA Editions, Paris

Bartley R, Roth CH, Ludwig J, McJannet D, Liedloff A, Corfield J, Hawdon A, Abbott B (2006) Runoff and erosion from Australia's tropical semi-arid rangelands: influence of ground cover for differing space and time scales. Hydrol Process 20:3317-3333. doi:10. 1002/hyp.6334

Bathurst JC (1986) Sensitivity analysis of the Systeme Hydrologique Europeen for an upland catchment. J Hydrol 87:103-123. doi:10. 1016/0022-1694(86)90117-4 
Beckers E, Degré A (2011) Revue bibliographique: La prise en compte des transferts horizontaux dans les modèles hydrologiques. Biotechnol Agron Soc Environ 15:143-151

Beven KJ, Kirkby MJ (1979) A physically based, variable contributing area model of basin hydrology. Hydrol Sci Bull 24:43-69

Biarnes A, Colin F (2006) Methodology to assess the hydrological impact of weed control practices with a view to management of Mediterranean winegrowing catchments. Int J Sust Dev 9:161179. doi:10.1504/IJSD.2006.011639

Bicknell BR, Imhoff JC, Kittle JL Jr, Donigian AS Jr, Johanson RC, Barnwell TO (1996) Hydrological Simulation Program-Fortran user's manual for release 11. United States Environmental Protection Agency, USA

Bingner RL, Theurer FD, Yuan Y (2011) AnnAGNPS technical processes documentation version 5.2 DRAFT. United States Department of Agriculture. ftp://199.133.90.201/pub/outgoing/AGNPS/AGNPS Web_Files/pdf_files/Technical_Documentation.pdf. Accessed $1 \overline{\overline{7}}$ Mar 2013

Birkved M, Hauschild MZ (2006) PestLCI — a model for estimating field emissions of pesticides in agricultural LCA. Ecol Model 198:433451. doi:10.1016/j.ecolmodel.2006.05.035

Blanchard PE, Lerch RN (2000) Watershed vulnerability to losses of agricultural chemicals: interactions of chemistry, hydrology, and land-use. Environ Sci Technol 34:3315-3322. doi:10.1021/es991115+

Bockstaller C, Guichard L, Makowski D, Aveline A, Girardin P, Plantureux S (2008) Agri-environmental indicators to assess cropping and farming systems. A review. Agron Sustain Dev 28:139-149. doi:10.1051/agro:2007052

Borah DK, Bera M (2003) Watershed-scale hydrologic and nonpointsource pollution models: review of mathematical bases. Trans ASAE 46:1553-1566

Borah DK, Bera M (2004) Watershed-scale hydrologic and nonpointsource pollution models: review of applications. Trans ASAE 47:789-803

Brisson N, Launay M, Mary B, Beaudoin N (2009) Conceptual basis, formalisations and parameterization of the STICS crop model. Editions Quae, Paris

Cabidoche YM, Lesueur-Jannoyer M (2012) Contamination of harvested organs in root crops grown on chlordecone-polluted soils. Pedosphere 22:562-571. doi:10.1016/S1002-0160(12)60041-1

Calvet R, Barriuso E, Benoit P, Charnay MP, Coquet Y (2005) Les pesticides dans le sol. Conséquences agronomiques et environnementales. France Agricole Editions, Paris

Campbell NS, D'Arcy B, Frost A, Novotny V, Sansom A (2004) Diffuse pollution: an introduction to the problems and solutions. IWA, London

Capel PD, Larson SJ, Winterstein TA (2001) The behaviour of 39 pesticides in surface waters as a function of scale. Hydrol Process 15:1251-1269. doi:10.1002/hyp.212

Carluer N, Giannone G, Bazin PH, Cherif R, Gril JJ (2008) Vers un outil de dimensionnement des dispositifs enherbés pour limiter les flux de phytosanitaires transférés par ruissellement-Tests de scénarios. Ingénierie 55-56:61-77

Carof M, de Tourdonnet S, Saulas P, Floch DL, Roger-Estrade J (2007) Undersowing wheat with different living mulches in a no-till system. I. Yield analysis. Agron Sustain Dev 27:347-356. doi:10.1051/ agro:2007016

Carsel RF, Mulkey LA, Lorber MN, Baskin LB (1985) The Pesticide Root Zone Model (PRZM): a procedure for evaluating pesticide leaching threats to groundwater. Ecol Model 30:49-69. doi:10.1016/ 0304-3800(85)90036-5

Cerdan O, Le Bissonnais Y, Govers G, Lecomte V, van Oost K, Couturier A, King C, Dubreuil N (2004) Scale effect on runoff from experimental plots to catchments in agricultural areas in Normandy. J Hydrol 299:4-14. doi:10.1016/j.jhydrol.2004.02.017

Chapman R, Stranger JW (1992) Horticultural pesticide residues in water: a review of the potential for water contamination by pesticides used in the vegetable industry in Victoria. Department of Food and Agriculture, East Melbourne

Charlier JB (2007) Fonctionnement et modélisation hydrologique d'un petit bassin versant cultivé en milieu volcanique tropical. Ph.D. thesis, Université Montpellier II

Charlier J-B, Cattan P, Voltz M, Moussa R (2009) Transport of a nematicide in surface and groundwaters in a tropical volcanic catchment. J Environ Qual 38:1031-1041. doi:10.2134/jeq2008.0355

Cresswell HP, Painter DJ, Cameron KC (1993) Tillage and water content effects on surface soil hydraulic properties and shortwave albedo. Soil Sci Soc Am J 57:816-824. doi:10.2136/sssaj1993. 03615995005700030031x

Daam MA, den Brink PJ (2009) Implications of differences between temperate and tropical freshwater ecosystems for the ecological risk assessment of pesticides. Ecotoxicology 19:24-37. doi:10.1007/ s10646-009-0402-6

Dabney SM (1998) Cover crop impacts on watershed hydrology. J Soil Water Conserv 53:207-213

de Bruyn B, Freissinet C, Vauclin M (2006) An indice for pesticide potential vulnerability of surface waters: assessment on the Leysse catchment (Savoie). Houille Blanche 2:106-112. doi:10.1051/lhb:200602014

de Schampheleire M, Nuyttens D, Dekeyser D, Verboven P, Spanoghe P (2008) Interception of spray drift by border structures. Part 2: field experiments. Commun Agric Appl Biol Sci 73:723-727

Desneux N, Decourtye A, Delpuech J-M (2007) The sublethal effects of pesticides on beneficial arthropods. Annu Rev Entomol 52:81-106. doi:10.1146/annurev.ento.52.110405.091440

Devillers J, Farret R, Girardin P, Rivière JL, Soulas G (2005) Indicateurs pour évaluer les risques liés à l'utilisation des pesticides, Lavoisier. Tec et Doc, Paris

DHI (2007a) MIKE SHE user manual. Volume 1: user guide. DHI Water \& Environment, Hørsholm

DHI (2007b) MIKE SHE user manual. Volume 2: reference guide. DHI Water \& Environment, Hørsholm

di Guardo A, Calamari D, Zanin G, Consalter A, Mackay D (1994) A fugacity model of pesticide runoff to surface water: development and validation. Chemosphere 28:511-531. doi:10.1016/00456535(94)90295-X

Dietrich AM, Gallagher DL (2002) Fate and environmental impact of pesticides in plastic mulch production runoff: field and laboratory studies. J Agric Food Chem 50:4409-4416. doi:10.1021/jf0107454

Donigian AS, Bicknell BR, Imhoff JC (1995) Hydrological Simulation Program-Fortran (HSPF). In: Singh VP (ed) Computer models of watershed hydrology. Water Resources, Littleton, pp 395-442

Dubus IG, Surdyk N (2006) State-of-the-art. Review on pesticide fate models and environmental indicators. Report DL\#4 of the FP6 EUfunded FOOTPRINT project. http://www.eu-footprint.org/ downloads/FOOTPRINT_DL4.pdf. Accessed 16 Mar 2013

Dusek J, Ray C, Alavi G, Vogel T, Sanda M (2010) Effect of plastic mulch on water flow and herbicide transport in soil cultivated with pineapple crop: a modeling study. Agric Water Manag 97:16371645, doi: 16/j.agwat.2010.05.019

Ellis MCB, Miller PCH (2010) The Silsoe Spray Drift Model: a model of spray drift for the assessment of non-target exposures to pesticides. Biosyst Eng 107:169-177. doi:10.1016/j.biosystemseng.2010.09. 003

Farlin J, Gallé T, Bayerle M, Pittois D, Braun C, El Khabbaz H, Elsner M, Maloszewski $\mathrm{P}$ (2013) Predicting pesticide attenuation in a fractured aquifer using lumped-parameter models. Groundwater 51:276-285. doi:10.1111/j.1745-6584.2012.00964.x

Findeling A, Ruy S, Scopel E (2003) Modeling the effects of a partial residue mulch on runoff using a physically based approach. J Hydrol 275:49-66. doi:10.1016/S0022-1694(03)00021-0

Finizio A, Calliera M, Vighi M (2001) Rating systems for pesticide risk classification on different ecosystems. Ecotoxicol Environ Saf 49:262-274. doi:10.1006/eesa.2001.2063 
Foltz RB (2012) A comparison of three erosion control mulches on decommissioned forest road corridors in the northern Rocky Mountains, United States. J Soil Water Conserv 67:536-544. doi:10.2489/jswc.67.6.536

Fournier J (2006) Births of chemical crop protection. Actual Chim 298:43-53

Galiulin RV, Bashkin VN, Galiulina RA (2002) Review: behavior of persistent organic pollutants in the air-plant-soil system. Water Air Soil Pollut 137:179-191. doi:10.1023/A:1015558526154

Ganzelmeier H, Rautmann D, Spangenberg R, Streloke M, Herrmann M, Wenzelburger HJ, Walter HF (1995) Studies on the spray drift of plant protection products - results of a test program carried out throughout the Federal Republic of Germany. Blackwell Wissenschaftverlag, Berlin

Gárfias J, Verrette J-L, Antigüedad I, André C (1996) Choix d'un modèle pluie-ruissellement pour des conditions hydrologiques complexes. J Hydrol 176:227-247. doi:10.1016/0022-1694(95)02772-6

Gil Y, Sinfort C (2005) Emission of pesticides to the air during sprayer application: a bibliographic review. Atmos Environ 39:5183-5193. doi:10.1016/j.atmosenv.2005.05.019

Gish TJ, Sadeghi A, Wienhold BJ (1995) Volatilization of alachlor and atrazine as influenced by surface litter. Chemosphere 31:29712982. doi:10.1016/0045-6535(95)00157-4

Gumiere SJ, Raclot D, Cheviron B, Davy G, Louchart X, Fabre J-C, Moussa R, Bissonnais YL (2010) MHYDAS-Erosion: a distributed single-storm water erosion model for agricultural catchments. Hydrol Process 25:1717-1728. doi:10.1002/hyp.7931

Hartwig NL, Ammon HU (2002) Cover crops and living mulches. Weed Sci 50:688-699. doi:10.1614/0043-1745(2002)050[0688:AIACCA]2.0. $\mathrm{CO} ; 2$

Hewitt AJ (2001) Drift filtration by natural and artificial collectors: a literature review. Spray Drift Task Force, Macon

Hjorth K, Johansen K, Holen B, Andersson A, Christensen HB, Siivinen $\mathrm{K}$, Toome M (2011) Pesticide residues in fruits and vegetables from South America: a Nordic project. Food Control 22:1701-1706. doi:10.1016/j.foodcont.2010.05.017

Holvoet K, Seuntjens P, Vanrolleghem PA (2007) Monitoring and modeling pesticide fate in surface waters at the catchment scale. Ecol Model 209:53-64. doi:10.1016/j.ecolmodel.2007.07.030

Holvoet K, van Griensven A, Gevaert V, Seuntjens P, Vanrolleghem PA (2008) Modifications to the SWAT code for modelling direct pesticide losses. Environ Model Softw 23:72-81. doi:10.1016/j.envsoft. 2007.05.002

Huang X, Pedersen T, Fischer M, White R, Young TM (2004) Herbicide runoff along highways. 1. Field observations. Environ Sci Technol 38:3263-3271. doi:10.1021/es034847h

Jarvis NJ, Hollis JM, Nicholls PH, Mayr T, Evans SP (1997) MACRO - DB: a decision-support tool for assessing pesticide fate and mobility in soils. Environ Model Softw 12:251-265. doi:10. 1016/S1364-8152(97)00147-3

Jones JA, Swanson FJ, Wemple BC, Snyder KU (2000) Effects of roads on hydrology, geomorphology, and disturbance patches in stream networks. Conserv Biol 14:76-85. doi:10.1046/j.1523-1739.2000. 99083.x

Julien PY, Saghafian B, Ogden FL (1995) Raster-based hydrologic modelling of spatially-varied surface runoff. J Am Water Resour Assoc 31:523-536. doi:10.1111/j.1752-1688.1995.tb04039.x

Kasirajan S, Ngouajio M (2012) Polyethylene and biodegradable mulches for agricultural applications: a review. Agron Sustain Dev 32:501-529. doi:10.1007/s13593-011-0068-3

Kauark Leite LA (1990) Réflexions sur l'utilité des modèles mathématiques dans la gestion de la pollution diffuse d'origine agricole. Ph.D. thesis, Ecole Nationale des Ponts et Chaussées

Knisel WG, Walter G (1980) CREAMS: a field scale model for chemicals, runoff and erosion from agricultural management systems. United States Department of Agriculture, Washington, DC
Knisel WG, Walter G (1993) GLEAMS: Groundwater Loading Effects of Agricultural Management Systems. University of Georgia, Biological and Agricultural Engineering Department, Athens

Knisel WG, Leonard RA, Davis FM (1989) Agricultural management alternatives: GLEAMS model simulations. In: Proceedings of the 1989 Summer Computer Simulation Conference. The Society, San Diego, pp 701-706

Knisel WG, Leonard RA, Davis FM (1995) Representing management practices in GLEAMS. Eur J Agron 4:499-505

Kogan M (1998) Integrated pest management: historical perspectives and contemporary developments. Annu Rev Entomol 43:243-270. doi:10.1146/annurev.ento.43.1.243

Köhne JM, Köhne S, Šimůnek J (2009a) A review of model applications for structured soils: a) water flow and tracer transport. J Contam Hydrol 104:4-35. doi:10.1016/j.jconhyd.2008.10.002

Köhne JM, Köhne S, Šimůnek J (2009b) A review of model applications for structured soils: b) pesticide transport. J Contam Hydrol 104:3660. doi:10.1016/j.jconhyd.2008.10.003

Kreuger J (1998) Pesticides in stream water within an agricultural catchment in southern Sweden, 1990-1996. Sci Total Environ 216:227251. doi:10.1016/S0048-9697(98)00155-7

Kruhm-Pimpl M (1993) Pesticides in surface-water-analytical results for drinking-water reservoirs and bank filtrate waters. Acta Hydrochim Hydrobiol 21:145-152. doi:10.1002/aheh. 19930210303

Lacas JG, Voltz M, Gouy V, Carluer N, Gril JJ (2005) Using grassed strips to limit pesticide transfer to surface water: a review. Agron Sustain Dev 25:253-266. doi:10.1051/agro:2005001

Lacas JG, Carluer N, Voltz M (2012) Efficiency of a grass buffer strip for limiting diuron losses from an uphill vineyard towards surface and subsurface waters. Pedosphere 22:580-592. doi:10.1016/S10020160(12)60043-5

Lagacherie P, Rabotin M, Colin F, Moussa R, Voltz M (2010) GeoMHYDAS: a landscape discretization tool for distributed hydrological modeling of cultivated areas. Comput Geosci 36:1021-1032. doi:10.1016/j.cageo.2009.12.005

Larsbo M, Jarvis NJ (2003) MACRO 5.0. A model of water flow and solute transport in macroporous soil. Technical description. Swedish University of Agricultural Sciences, Sweden

Larson SJ, Capel PD, Goolsby DA, Zaugg SD, Sandstrom MW (1995) Relations between pesticide use and riverine flux in the Mississippi River basin. Chemosphere 31:3305-3321. doi:10.1016/00456535(95)00176-9

Leistra M, van der Linden AMA, Boesten JJTI, Tiktak A, van den Berg F (2001) PEARL model for pesticide behaviour and emissions in soilplant systems - descriptions of the processes in FOCUS PEARL $\mathrm{v}$ 1.1.1. Alterra, Green World Research, Wageningen

Leonard RA (1990) Movement of pesticides into surface waters. In: Cheng HH (ed) Pesticides in the soil environment: processes, impacts, and modeling. Soil Science Society of America, Madison, pp 303-349

Leonard RA, Knisel WG, Still DA (1987) GLEAMS: Groundwater Loading Effects of Agricultural Management Systems. Trans ASAE 30:1403-1418

Levavasseur F, Bailly JS, Lagacherie P, Colin F, Rabotin M (2012) Simulating the effects of spatial configurations of agricultural ditch drainage networks on surface runoff from agricultural catchments. Hydrol Process 26:3393-3404. doi:10.1002/hyp.8422

Levillain J, Cattan P, Colin F, Voltz M, Cabidoche Y-M (2012) Analysis of environmental and farming factors of soil contamination by a persistent organic pollutant, chlordecone, in a banana production area of French West Indies. Agric Ecosyst Environ 159:123-132. doi:10.1016/j.agee.2012.07.005

LimnoTech (2010) Blanchard watershed annAGNPS modeling-final report. LimnoTech, Ann Arbor 
Lin CY, Chou WC, Lin WT (2002) Modeling the width and placement of riparian vegetated buffer strips: a case study on the Chi-Jia-Wang Stream, Taiwan. J Environ Manag 66:269-280. doi:10.1006/jema. 2002.0589

Luo Y, Zhang M (2009) Management-oriented sensitivity analysis for pesticide transport in watershed-scale water quality modeling using SWAT. Environ Pollut 157:3370-3378. doi:10.1016/j.envpol.2009. 06.024

Ma L, Ahuja LR, Ascough JC II, Shaffer MJ, Rojas KW, Malone RW, Cameira MR (2001) Integrating system modeling with field research in agriculture: applications of the root zone water quality model (RZWQM). Adv Agron 71:233-292. doi:10.1016/S0065-2113(01) 71016-4

Mackay D (2001) Multimedia environmental models: the fugacity approach. Lewis-CRC, Boca Raton

Madrigal I (2004) Rétention de pesticides dans les sols des dispositifs tampon, enherbés et boisés. Rôle des matières organiques. Ph.D. thesis, Institut National Agronomique de Paris-Grignon

Madrigal I, Benoit P, Barriuso E, Etiévant V, Souiller C, Real B, Dutertre A (2002) Capacité de stockage et d'épuration des sols de dispositifs enherbés vis-à-vis des produits phytosanitaires. Deuxième partie : Propriétés de rétention de deux herbicides, l'isoproturon et le diflufénicanil dans différents sols de bandes enherbées. Etude Gest Sol 6:287-302

Magliola C, Knisel WG (1992) Impact of agriculture on water quality in Circeo National Park, Italy: a model study. I-Pesticides. In: Balducci S, Crema G, di Bartolomeo G, Formigoni G, Merlo C (eds) Aquater 1972-1992, Venti Anni per le Risorse Naurali. Aquater, San Lorenzo in Campo, pp 293-301

Malézieux E (2012) Designing cropping systems from nature. Agron Sustain Dev 32:15-29. doi:10.1007/s13593-011-0027-z

Malézieux E, Crozat Y, Dupraz C, Laurans M, Makowski D, OzierLafontaine H, Rapidel B, de Tourdonnet S, Valantin-Morison M (2009) Mixing plant species in cropping systems: concepts, tools and models. A review. Agron Sustain Dev 29:43-62. doi:10.1051/ agro:2007057

Malone RW, Ahuja LR, Ma L, Don Wauchope R, Ma Q, Rojas KW (2004) Application of the Root Zone Water Quality Model (RZWQM) to pesticide fate and transport: an overview. Pest Manag Sci 60:205-221. doi:10.1002/ps.789

Maraite H, Steurbaut W, Debongnie W (2004) Development of awareness tools for a sustainable use of pesticides. Belgian Science Policy, Brussels. http://www.belspo.be/belspo/organisation/Publ/pub_ostc/ CPagr/rappCP33 en.pdf. Accessed 17 Jan 2013

Martin P, Joannon A, Mignolet C, Souchère V, Thenail C (2006) Systèmes de culture et territoires: Cas des questions environnementales. In: Doré T, Le Bail M, Martin P, Ney B, Roger-Estrade J (eds) L'agronomie aujourd'hui. Editions Quae, Versailles, pp 253-284

Maybank J, Yoshida K, Grover R (1978) Spray drift from agricultural pesticide applications. J Air Pollut Control Assoc 28:1009-1014. doi:10.1080/00022470.1978.10470699

Meynard J-M, Doré T, Habib R (2001) L'évaluation et la conception de systèmes de culture pour une agriculture durable. CR Acad Agric Fr 87:223-236

Mohamoud YM, Parmar R, Wolfe K (2010) Modeling Best Management Practices (BMPs) with HSPF. Innovations in watershed management underland use and climate change. American Society of Civil Engineers, Madison, pp 892-898

Moonen A, Marshall EJ (2001) The influence of sown margin strips, management and boundary structure on herbaceous field margin vegetation in two neighbouring farms in southern England. Agric Ecosyst Environ 86:187-202. doi:10.1016/S0167-8809(00)00283-8

Moore MT, Bennett ER, Cooper CM, Smith S, Shields FD, Milam CD, Farris JL (2001) Transport and fate of atrazine and lambdacyhalothrin in an agricultural drainage ditch in the Mississippi
Delta, USA. Agric Ecosyst Environ 87:309-314. doi:10.1016/ S0167-8809(01)00148-7

Moore MT, Denton DL, Cooper CM, Wrysinski J, Miller JL, Werner I, Horner G, Crane D, Holcomb DB, Huddleston GM 3rd (2011) Use of vegetated agricultural drainage ditches to decrease pesticide transport from tomato and alfalfa fields in California, USA. Environ Toxicol Chem 30:1044-1049. doi:10.1002/etc.474

Morgan RPC, Quinton JN, Smith RE, Govers G, Poesen JWA, Auerswald K, Chisci G, Torri D, Styczen ME (1998) The European Soil Erosion Model (EUROSEM): a dynamic approach for predicting sediment transport from fields and small catchments. Earth Surf Process Landforms 23:527-544. doi:10.1002/(SICI) 1096-9837(199806)23:6<527::AID-ESP868>3.0.CO;2-5

Moussa R, Voltz M, Andrieux P (2002) Effects of the spatial organization of agricultural management on the hydrological behaviour of a farmed catchment during flood events. Hydrol Process 16:393412. doi:10.1002/hyp.333

Moussa R, Voltz M, Andrieux P, Servat E, Najem W, Leduc C, Shakeel A (2003) Impacts of various scenarios of agricultural management on the hydrological behaviour of a farmed catchment during flood events. In: Servat E, Najem W, Leduc C, Shakeel A (eds) Hydrology in Mediterranean and semiarid regions. International Association of Hydrological Sciences, Montpellier, pp 417-421

Moussa R, Colin F, Dagès C, Fabre J-C, Lagacherie P, Louchart X, Rabotin M, Raclot D, Voltz M (2010) Distributed hydrological modelling of farmed catchments (MHYDAS): assessing the impact of man-made structures on hydrological processes. LandMod 2010: International Conference on Integrative Landscape Modelling. Quæ, Montpellier, pp 1-14

Neitsch SL, Arnold JG, Kiniry JR, Williams JR (2011) Soil and Water Assessment Tool: theoretical documentation version 2009. Texas Water Resources Institute, College Station

Norris LA (1974) Behavior of pesticides in plants. U.S. Department of Agriculture-Forest Service, Portland

Passeport E, Tournebize J, Chaumont C, Guenne A, Coquet Y (2013) Pesticide contamination interception strategy and removal efficiency in forest buffer and artificial wetland in a tile-drained agricultural watershed. Chemosphere 91:1289-1296. doi:10.1016/j.chemosphere. 2013.02.053

Payraudeau S, Gregoire C (2012) Modelling pesticides transfer to surface water at the catchment scale: a multi-criteria analysis. Agron Sustain Dev 32:479-500. doi:10.1007/s13593-011-0023-3

Ponce VM, Hawkins RH (1996) Runoff curve number: has it reached maturity? J Hydrol Eng 1:11-19. doi:10.1061/(ASCE)10840699(1996)1:1(11)

Quilbé R, Rousseau AN (2007) GIBSI: an integrated modelling system for watershed management - sample applications and current developments. Hydrol Earth Syst Sci 11:1785-1795. doi:10.5194/hess11-1785-2007

Quilbé R, Rousseau AN, Lafrance P, Leclerc J, Amrani M (2006) Selecting a pesticide fate model at the watershed scale using a multi-criteria analysis. Water Qual Res J Canada 41:283-295

Raphael L, Sierra J, Recous S, Ozier-Lafontaine H, Desfontaines L (2012) Soil turnover of crop residues from the banana (Musa AAA cv. Petite-Naine) mother plant and simultaneous uptake by the daughter plant of released nitrogen. Eur J Agron 38:117-123. doi:10.1016/j.eja.2011.07.005

Ravier I, Haouisee E, Clement M, Seux R, Briand O (2005) Field experiments for the evaluation of pesticide spray-drift on arable crops. Pest Manag Sci 61:728-736. doi:10.1002/ps.1049

Real B (2004) Démarche proposée par le CORPEN pour l'estimation des risques de contamination des eaux. In: Barriuso E (ed) Estimation des risques environnementaux des pesticides. INRA Editions, Paris, pp 87-103

Refsgaard JC, Storm B (1995) MIKE SHE. In: Singh VP (ed) Computer models of watershed hydrology. Water Resources, Littleton, pp 809-846 
Reichenberger S, Bach M, Skitschak A, Frede H-G (2007) Mitigation strategies to reduce pesticide inputs into ground and surface water and their effectiveness; a review. Sci Total Environ 384:1-35. doi:10.1016/j.scitotenv.2007.04.046

Renard KG, Foster GR, Weesies GA, McCool DK, Yoder DC (1997) Predicting soil erosion by water: a guide to conservation planning with the Revised Universal Soil Loss Equation (RUSLE). US Government Printing Office, Washington, DC

Rice PJ, McConnell LL, Heighton LP, Sadeghi AM, Isensee AR, Teasdale JR, Abdul-Baki AA, Harman-Fetcho JA, Hapeman CJ (2001) Runoff loss of pesticides and soil: a comparison between vegetative mulch and plastic mulch in vegetable production systems. J Environ Qual 30:1808-1821

Rice PJ, Rice PJ, Arthur EL, Barefoot AC (2007) Advances in pesticide environmental fate and exposure assessments. J Agric Food Chem 55:5367-5376. doi:10.1021/jf063764s

Ripoche A, Jacqua G, Bussière F, Guyader S, Sierra J (2008) Survival of Colletotrichum gloeosporioides (causal agent of yam anthracnose) on yam residues decomposing in soil. Appl Soil Ecol 38:270-278. doi:10.1016/j.apsoil.2007.10.015

Roger-Estrade J, Richard G, Dexter AR, Boizard H, Tourdonnet S, Bertrand M, Caneill J (2009) Integration of soil structure variations with time and space into models for crop management. A review. Agron Sustain Dev 29:135-142. doi:10.1051/agro:2008052

Rojas KW, Ahuja LR (2000) Chapter 8: Management Practices. In: Ahuja LR, Rojas KW, Hanson JD, Shaffer MJ, Ma L (eds) Root Zone Water Quality Model: modelling management effects on water quality and crop production. Water Resources, Littleton, pp 245 280

Rosset PM, Altieri MA (1997) Agroecology versus input substitution: a fundamental contradiction of sustainable agriculture. Soc Nat Resour 10:283-295. doi:10.1080/08941929709381027

Roussel O, Cavelier A, van der Werf HMG (2000) Adaptation and use of a fuzzy expert system to assess the environmental effect of pesticides applied to field crops. Agric Ecosyst Environ 80:143-158. doi:10. 1016/S0167-8809(00)00142-0

Schiavon M, Perrin-Ganier C, Portal J (1995) La pollution de l'eau par les produits phytosanitaires: Etat et origine. Agronomie 15:157-170. doi:10.1051/agro:19950301

Schulz R (2001) Comparison of spray drift and runoff-related input of azinphos-methyl and endosulfan from fruit orchards into the Lourens River, South Africa. Chemosphere 45:543-551. doi:10. 1016/S0045-6535(00)00601-9

Shaman J, Stieglitz M, Burns D (2004) Are big basins just the sum of small catchments? Hydrol Process 18:3195-3206. doi:10.1002/hyp.5739

Sharpley AN, Williams JR (1990) Erosion productivity impact calculator: 1. Model documentation. U.S. Department of Agriculture, Agricultural Research Service, Temple

Shasha BS, Doane WM, Russell CR (1976) Starch-encapsulated pesticides for slow release. J Polym Sci Pol Lett 14:417-420. doi:10. 1002/pol.1976.130140708

Siimes K, Kämäri J (2003) A review of available pesticide leaching models: selection of models for simulation of herbicide fate in Finnish sugar beet cultivation. Boreal Environ Res 8:31-51

Simunek J, Jarvis NJ, van Genuchten MT, Gärdenäs A (2003) Review and comparison of models for describing non-equilibrium and preferential flow and transport in the vadose zone. J Hydrol 272:14-35. doi:10.1016/S0022-1694(02)00252-4

Sinclair RG (1973) Slow-release pesticide system. Polymers of lactic and glycolic acids as ecologically beneficial, cost-effective encapsulating materials. Environ Sci Technol 7:955-956. doi:10.1021/ es60082a011

Sivapalan M (2006) Pattern, process and function: elements of a unified theory of hydrology at the catchment scale. In: Anderson MG, McDonnell JJ (eds) Encyclopedia of hydrological sciences. Wiley, USA, pp 193-219
Srinivasan R, Ramanarayanan TS, Arnold JG, Bednarz ST (1998) Large area hydrologic modeling and assessment part II: model application. J Am Water Resour Assoc 34:91-101. doi:10.1111/j.1752-1688. 1998.tb05962.x

Stenemo F, Jarvis NJ (2010) Users guide to MACRO 5.2, a model of water flow and solute transport in macroporous soil. Swedish University of Agricultural Sciences, Stockholm

Styczen M, Thorsen M, Refsgaard A, Christiansen JS, Soren H (1999) Non-point pollution modelling at different scales and resolution, based on MIKE SHE. 3rd DHI Software Conference. Helsingør, Denmark, pp 1-25

Styczen M, Petersen S, Olsen NK, Andersen MB (2004) Technical documentation of PestSurf, a model describing fate and transport of pesticides in surface water for Danish conditions. Ministry of Environment, Danish Environmental Protection Agency. http:// www.dhigroup.com/upload/publications/mikeshe/Styczen Technical_documentation.pdf. Accessed 16 Mar 2013

Suarez LA (2005) PRZM-3, a model for predicting pesticide and nitrogen fate in the crop root and unsaturated soil zones: user's manual for release 3.12.2. U.S. Environmental Protection Agency, Washington, DC

Takken I, Govers G, Jetten V, Nachtergaele J, Steegen A, Poesen J (2001) Effects of tillage on runoff and erosion patterns. Soil Tillage Res 61:55-60. doi:10.1016/S0167-1987(01)00178-7

Tanji KK (1993) Ground water contamination concerns in horticultural production systems. Acta Horticult 355:37-44

Thiollet-Scholtus M (2004) Construction d'un indicateur de qualité des eaux de surfaces vis à vis des produits phytosanitaires à l'échelle du bassin versant viticole. Ph.D. thesis, Institut National Polytechnique de Lorraine

Tiemeyer B, Moussa R, Lennartz B, Voltz M (2007) MHYDAS-DRAIN: a spatially distributed model for small, artificially drained lowland catchments. Ecol Model 209:2-20. doi:10.1016/j.ecolmodel.2007.07.003

Tiktak A, van den Berg F, Boesten JJTI, van Kraalingen D, Leistra M, van der Linden AMA (2000) Manual of FOCUS PEARL version 1.1.1. National institute of public health and the environment, Bilthoven

Tiktak A, Nie DD, Linden TVD, Kruijne R (2002) Modelling the leaching and drainage of pesticides in the Netherlands: the GeoPEARL model. Agronomie 22:373-387. doi:10.1051/ agro:2002022

Tiktak A, van der Linden AMA, Boesten JJTI (2003) The GeoPEARL model, model description, application and manual. National Institute of Public Health and the Environment, Bilthoven

Tiktak A, van der Linden AMA, Boesten JJTI, Kruijne R, van Kraalingen D (2004) The GeoPEARL model. Part II. User guide and model description update. National Institute of Public Health and the Environment, Bilthoven

Tilman D, Cassman KG, Matson PA, Naylor R, Polasky S (2002) Agricultural sustainability and intensive production practices. Nature 418:671-677. doi:10.1038/nature01014

Tixier P (2004) Prototyping of banana-based cropping systems using models: an application to cropping systems of Guadeloupe F.W.I. $\mathrm{Ph} . \mathrm{D}$. thesis, Ecole Nationale Supérieure Agronomique de Montpellier

Tixier P, Malézieux E, Dorel M, Bockstaller C, Girardin P (2007) Rpest - an indicator linked to a crop model to assess the dynamics of the risk of pesticide water pollution: application to banana-based cropping systems. Eur J Agron 26:71-81. doi:10.1016/j.eja.2006.08.006

Tixier P, Lavigne C, Alvarez S, Gauquier A, Blanchard M, Ripoche A, Achard R (2011) Model evaluation of cover crops, application to eleven species for banana cropping systems. Eur J Agron 34:53-61. doi:10.1016/j.eja.2010.10.004

Tortrat F (2005) Modélisation orientée décision des processus de transfert par ruissellement et subsurface des herbicides dans les bassins versants agricoles. Ph.D. thesis, Ecole Nationale Supérieure Agronomique de Rennes-AgroCampus Rennes 
Ucar T, Hall FR (2001) Windbreaks as a pesticide drift mitigation strategy: a review. Pest Manag Sci 57:663-675. doi:10.1002/ps.341

USDA (1986) Urban hydrology for small watersheds. USDA, Soil Conservation Service, Engineering Division, Washington, DC

USDA (2012) NRCS National Engineering Handbook-Part 630/ Hydrology. USDA, National Resources Conservation Service. http://directives.sc.egov.usda.gov/viewerFS.aspx?hid=21422. Accessed 06 Jul 2012

van der Keur P, Henriksen H, Sonnenborg T, van Roosmalen L, Rosenbom AE, Olesen JE, Kjaer J, Jørgensen LN, Christensen OB (2011) Catchment scale modelling of changes in pesticide leaching under present and future climate conditions. Demonstrated for two cases in Denmark. Abstract for 2011 Fall Meeting, American Geophysical Union (AGU)

van der Werf HMG (1996) Assessing the impact of pesticides on the environment. Agric Ecosyst Environ 60:81-96. doi:10.1016/S01678809(96)01096-1

van der Werf HMG, Zimmer C (1998) An indicator of pesticide environmental impact based on a fuzzy expert system. Chemosphere 36:2225-2249. doi:10.1016/S0045-6535(97)10194-1

van Dijk HFG, Guicherit R (1999) Atmospheric dispersion of current-use pesticides: a review of the evidence from monitoring studies. Water Air Soil Pollut 115:21-70. doi:10.1023/A:1005293020536

van Dijk PM, Kwaad FJPM, Klapwijk M (1996) Retention of water and sediment by grass strips. Hydrol Process 10:1069-1080. doi:10.1002/ (SICI)1099-1085(199608)10:8<1069::AID-HYP412>3.0.CO;2-4

Vennix S, Northcott W (2004) Prioritizing vegetative buffer strip placement in an agricultural watershed. J Spat Hydrol 4:1-19

Walter MF, Steenhuis TS, Haith DA (1979) Nonpoint source pollution control by soil and water conservation practices. Trans ASAE 22:834-840

Warren N, Allan IJ, Carter JE, House WA, Parker A (2003) Pesticides and other micro-organic contaminants in freshwater sedimentary environments - a review. Appl Geochem 18:159-194. doi:10. 1016/S0883-2927(02)00159-2

Wauchope RD, Rojas KW, Ahuja LR, Ma Q, Malone RW, Ma L (2004) Documenting the pesticide processes module of the ARS RZWQM agroecosystem model. Pest Manag Sci 60:222-239. doi:10.1002/ps.814

Williams JR, Jones CA, Dyke PT (1984) A modeling approach to determining the relationship between erosion and soil productivity. Trans ASAE 27:129-144
Williams JR, Dyke PT, Fuchs WW, Benson VW, Rice OW, Taylor ED (1990) EPIC - Erosion/Productivity Impact Calculator: 2. user manual. U.S. Department of Agriculture, Agricultural Research Service, Temple

Winchell M, Estes T (2009) A review of simulation models for evaluating the effectiveness of buffers in reducing pesticide exposure. Stone Environmental, Inc. http://abe.ufl.edu/carpena/files/pdf/software/ vfsmod/RunoffBufferPaper_Final.pdf. Accessed 25 Sep 2012

Wischmeier WH, Smith DD (1978) Predicting rainfall erosion losses: a guide to conservation planning. U.S. Department of Agriculture, Washington, DC

Wohlfahrt J (2008) Développement d'un indicateur d'exposition des eaux de surface aux pertes de pesticides à l'échelle du bassin versant. Ph.D. thesis, Institut National Polytechnique de Lorraine

Wohlfahrt J, Colin F, Assaghir Z, Bockstaller C (2010) Assessing the impact of the spatial arrangement of agricultural practices on pesticide runoff in small catchments: combining hydrological modeling and supervised learning. Ecol Indic 10:826-839. doi:10.1016/j. ecolind.2010.01.004

Wu L, Swan JB, Paulson WH, Randall GW (1992) Tillage effects on measured soil hydraulic properties. Soil Tillage Res 25:17-33. doi:10.1016/0167-1987(92)90059-K

Young RA, Onstad CA, Bosch DD, Anderson WP (1989) AGNPS: a nonpoint-source pollution model for evaluating agricultural watersheds. J Soil Water Conserv 44:168-173

Young RA, Onstad CA, Bosch DD, Anderson WP (1994) Agricultural Non-Point Source pollution model, version 4.03, AGNPS user's guide. North Central Soil Conservation Research Laboratory, Morris

Yuan Y, Bingner RL, Williams R, Lowrance R, Bosch D, Sheridan J (2007) Integration of annAGNPS and REMM for watershed riparian buffer systems assessment. Int J Sediment Res 22:60-69

Yuan Y, Locke MA, Bingner RL (2008) Annualized Agricultural NonPoint Source model application for Mississippi Delta Beasley lake watershed conservation practices assessment. J Soil Water Conserv 63:542-551. doi:10.2489/jswc.63.6.542

Zhang X, Zhang M (2011) Modeling effectiveness of agricultural BMPs to reduce sediment load and organophosphate pesticides in surface runoff. Sci Total Environ 409:1949-1958. doi:10.1016/j.scitotenv. 2011.02.012 